OPEN ACCESS

Edited by:

Pietro Franceschi,

Fondazione Edmund Mach, Italy

Reviewed by:

Giuseppe Pieraccini,

University of Florence, Italy

Johannes Messinger,

Umeå University, Sweden

*Correspondence:

Gilles Peltier

gilles.peltier@cea.fr

tORCID:

Adrien Burlacot

orcid.org/0000-0001-7434-6416

François Burlacot

orcid.org/0000-0001-9783-6848

Yonghua Li-Beisson

orcid.org/0000-0003-1064-1816

Gilles Peltier

orcid.org/0000-0002-2226-3931

Specialty section:

This article was submitted to Technical Advances in Plant Science,

a section of the journal

Frontiers in Plant Science

Received: 18 May 2020

Accepted: 11 August 2020

Published: 04 September 2020

Citation:

Burlacot A, Burlacot F, Li-Beisson Y and Peltier G (2020) Membrane Inlet Mass Spectrometry: A Powerful Tool

for Algal Research.

Front. Plant Sci. 11:1302.

doi: 10.3389/fp/s.2020.01302

\section{Membrane Inlet Mass Spectrometry: A Powerful Tool for Algal Research}

\author{
Adrien Burlacot ${ }^{\dagger}$, François Burlacot ${ }^{\dagger}$, Yonghua Li-Beisson $^{\dagger}$ and Gilles Peltier ${ }^{*+}$ \\ Aix Marseille Univ, Commissariat à l'énergie Atomique et aux énergies Alternatives (CEA), Centre National de la Recherche \\ Scientifique (CNRS), Institut de Biosciences et Biotechnologies d'Aix-Marseille (BIAM), CEA Cadarache, Saint Paul-Lez- \\ Durance, France
}

Since the first great oxygenation event, photosynthetic microorganisms have continuously shaped the Earth's atmosphere. Studying biological mechanisms involved in the interaction between microalgae and cyanobacteria with the Earth's atmosphere requires the monitoring of gas exchange. Membrane inlet mass spectrometry (MIMS) has been developed in the early 1960s to study gas exchange mechanisms of photosynthetic cells. It has since played an important role in investigating various cellular processes that involve gaseous compounds $\left(\mathrm{O}_{2}, \mathrm{CO}_{2}, \mathrm{NO}\right.$, or $\left.\mathrm{H}_{2}\right)$ and in characterizing enzymatic activities in vitro or in vivo. With the development of affordable mass spectrometers, MIMS is gaining wide popularity and is now used by an increasing number of laboratories. However, it still requires an important theory and practical considerations to be used. Here, we provide a practical guide describing the current technical basis of a MIMS setup and the general principles of data processing. We further review how MIMS can be used to study various aspects of algal research and discuss how MIMS will be useful in addressing future scientific challenges.

\footnotetext{
Keywords: gas exchange, photosynthesis, carbonic anhydrase, $\mathrm{CO}_{2}$ concentrating mechanism, $\mathrm{O}_{2}$ evolution $\mathrm{H}_{2}$ production, microalgae, cyanobacteria
}

\section{HIGHLIGHTS}

Photosynthetic microoganisms are major actors shaping the Earth's atmosphere and limiting global warming by fixing $\mathrm{CO}_{2}$. We hereby describe practical and theoretical state of the art of the most polyvalent technique to measure gas exchange in microorganisms.

\section{INTRODUCTION}

Since its formation, the Earth's atmosphere has continuously been shaped by living organisms. Among all biological processes, oxygenic photosynthesis has dramatically changed the atmosphere composition by massively capturing $\mathrm{CO}_{2}$ and producing $\mathrm{O}_{2}$ during the Great Oxygenation Event that began 2.4 billion years ago with the emergence of cyanobacteria (Hohmann-Marriott and Blankenship, 2011). Nowadays, microalgae and cyanobacteria account for more than $50 \%$ of global photosynthesis (Field et al., 1998) and have a great importance in the regulation of atmospheric $\mathrm{CO}_{2}$ levels and global warming. Understanding biological mechanisms underlying $\mathrm{CO}_{2}$ capture or 
production of other greenhouse gases such as nitrous oxide $\left(\mathrm{N}_{2} \mathrm{O}\right)$ by microbial photosynthesis is of utmost relevance to better assess the impact of global changes on oceanic carbon sinks. It is also crucial to explore the limits of biomass productivity of algae and give some hints to assess the impact of microalgae-based biofuels on the environment (Burlacot et al., 2020a).

In the early 60s, Hoch and Kok (1963) designed a membrane inlet system coupled to a mass spectrometer (MIMS), which allowed the direct measurement of concentrations of dissolved $\mathrm{CO}_{2}$ and $\mathrm{O}_{2}$ in a microalgal suspension. In the MIMS setup they developed, a thin plastic membrane (polyethylene or Teflon) permeable to gases allowed part of the dissolved gases to pass from the microalgal suspension to the mass spectrometer. Coupled to the use of ${ }^{18} \mathrm{O}$-labeled $\mathrm{O}_{2}$, MIMS allowed in situ measurement of $\mathrm{O}_{2}$ uptake processes occurring during microalgal and cyanobacterial photosynthesis (Hoch and Kok, 1963; Gerster et al., 1974; Radmer and Kok, 1976; Gerster et al., 1977; Radmer and Ollinger, 1980b; Peltier and Thibault, 1985a; Peltier and Thibault, 1985b). The use of isotope-labeled water has also been an important tool for the study of water oxidation mechanisms by photosystem II (PSII) (Radmer and Ollinger, 1980a; Radmer and Ollinger, 1986; Shevela et al., 2011; Koroidov et al., 2014), which is not reviewed here and readers are referred to a recent review (Shevela and Messinger, 2013).

Later on, MIMS has been used to monitor various biological gases in the context of: $i$, inorganic carbon transport (Badger et al., 1994; Yu et al., 1994; Sültemeyer et al., 1998); ii, hydrogen production (van der Oost and Cox, 1988; Redding et al., 1999; Cournac et al., 2002; Tamburic et al., 2011); or iii, ethylene production (Zavrel et al., 2016). With the development of genetics tools, MIMS has been widely used to characterize various microalgae or cyanobacteria mutants and contributed to the understanding of molecular mechanisms involved in photosynthetic gas exchange (So et al., 1998; Hanson et al.,
2003; Helman et al., 2003; Cournac et al., 2004; Jans et al., 2008). It has also been used for in vitro studies of enzymes using gases as a substrate or products, like hydrogenases (Leroux et al., 2008), carbonic anhydrases (Northrop and Simpson, 1998) and the Fatty Acid Photodecarboxylase (Sorigué et al., 2017). In addition, it has also been used to study artificial catalysts for water oxidation (Poulsen et al., 2005; Koroidov et al., 2015) and to follow biogeochemical cycles in the oceans (Chua et al., 2016). Taken together, MIMS has made significant contributions to the fields of photosynthesis research, enzymology, biofuel research, and earth science which was recently reviewed (Burlacot et al., 2020a).

MIMS is nowadays a mature technique implicated in a growing number of applications in the field of algal research. With mass spectrometers being more affordable in the past years, MIMS is increasingly available in many laboratories. However, mounting and running a MIMS setup is technically and theoretically challenging. Previous reviews have focused on some specific aspects of MIMS in the context of photosynthesis research (Degn, 1992; Kotiaho and Lauritsen, 2002; Konermann et al., 2008; Beckmann et al., 2009; Shevela and Messinger, 2013; Cheah et al., 2014; Shevela et al., 2018). The current review intends to provide a guide covering theoretical, technical, and data processing aspects required for a broad usage of MIMS in algal research.

\section{MIMS SETUP, OPTIMIZATION AND DATA PROCESSING}

A typical MIMS setup is composed of five parts (Figure 1): (i), a reaction vessel containing the liquid medium/algal culture where gas exchange reactions take place; (ii), a membrane separating the liquid phase of the reaction vessel from the high vacuum line;

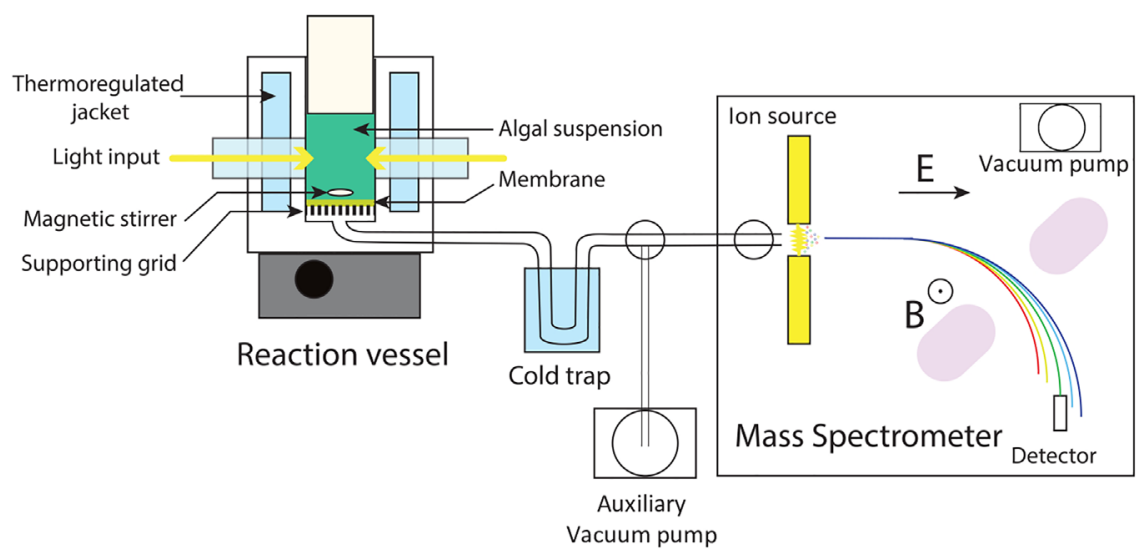

FIGURE 1 | Schematic setup of a Membrane Inlet Mass Spectrometry. The biological sample (cell suspension, cell free extract, or enzyme containing medium) is introduced inside a thermo-regulated reaction vessel equipped with a gas permeable membrane. Dissolved gases contained in the liquid medium pass through the membrane to a high vacuum tubing. After passing through a cold trap protecting the mass spectrometer from water leaks, gases enter the ion source of a mass spectrometer. Upon ionization, charged molecules are accelerated by an electric field (E), deviated by a magnetic field (B), and collected by a detector. An auxiliary vacuum pump allows for making the vacuum on the line with the closed inlet to the mass spectrometer. B, magnetic field; E, electric field. 
(iii), a vacuum line connecting the reaction vessel to the mass spectrometer; (iv), a cold trap protecting the mass spectrometer from water leakage; and (v), a mass spectrometer for gas analysis. MIMS allows measurement of any volatile compound, with a molar mass up to a hundred gram per mole, dissolved in liquid phase (Kotiaho and Lauritsen, 2002). MIMS operation requires proper material setup and appropriate data processing. Each of the technical parts needs to be optimized to ensure reliable and stable measurement.

\section{The Membrane Inlet}

The membrane is gas permeable and serves as a physical barrier between the liquid phase and the ion source of the mass spectrometer connected by a vacuum line. In the setup described in Figure $\mathbf{1}$ the membrane is held at the bottom of the reaction vessel supported by a stainless-steel grid. Note that different membrane inlet setups like microprobes can be used (Kotiaho and Lauritsen, 2002; Konermann et al., 2008). The gas leak through the membrane occurs through a three-step process called permeation: adsorption at the membrane surface, diffusion through the membrane material, and desorption on the other side of the membrane. In this process, diffusion is the limiting factor (Konermann et al., 2008) and is a temperature-dependent process. Thus, membrane permeability is highly influenced by temperature (Figure 2), and the reaction vessel must be precisely thermo-regulated (Figure 1). The gas leak is crucial since it defines the sensitivity of the method, especially it should remain small compared to the measured reaction rates to limit noise. Gas leakage depends on the membrane properties and is linearly related to the gas concentration inside the vessel (Methods S1). Various porous plastic films can be used as a membrane, although polytetrafluoroethylene (PTFE, also known as Teflon) and silicon are the most commonly used (Beckmann et al., 2009; Shevela et al., 2018). The permeability to gases depends on the

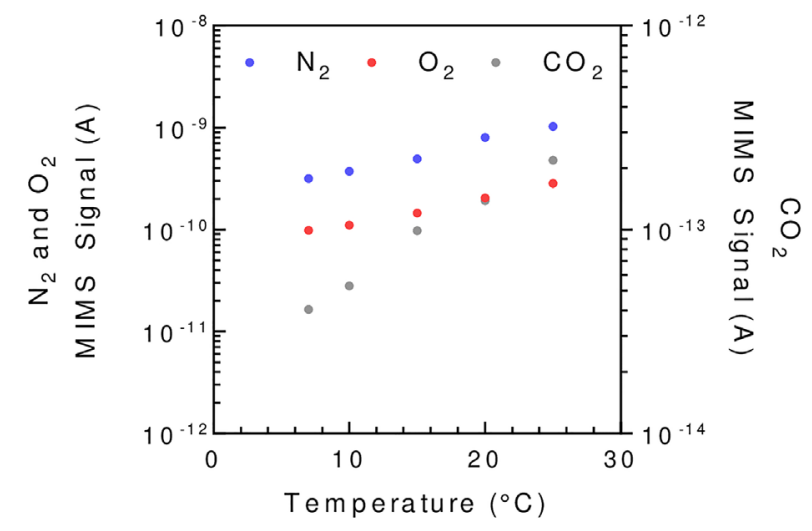

FIGURE 2 | The influence of temperature on the MIMS signal strength illustrated for $\mathrm{N}_{2}, \mathrm{O}_{2}$, and $\mathrm{CO}_{2}$. Reaction vessel is filled with $\mathrm{C}$. reinhardtii minimal growing medium buffered at $\mathrm{pH}=7.2$ using 3-( $\mathrm{N}$-morpholino) propane sulfonic acid (MOPS, $20 \mathrm{mM}$ final concentration) and is flushed with air until reaching steady state. A PTFE membrane $(13 \mu \mathrm{m})$ is used. To avoid solubility issues, the signal shown is normalized by the Bunsen coefficient (see Methods 1). The mass spectrometer signal is given in amperes (A). nature of the membrane. Silicon membranes are more permeable to gases than PTFE membranes (Lloyd et al., 1983) (PTFE membranes can be found on www.hansatech-instruments.com/ or www.ysi.com). The gas leak depends on both membrane surface and thickness, which must be chosen depending on the required sensitivity and on the duration of the experiments to be carried out. The ion source is overly sensitive to water that interferes with ionization and therefore quantification. In this respect, a PTFE membrane has the advantage over silicone of being seven times less permeable to water relatively to $\mathrm{N}_{2}$ (Jensen and Cox, 1988), resulting in less noise. A magnetic stirrer is used to maintain algae in suspension and homogenize the gas content of the liquid medium (Lundsgaard et al., 1978). In a case where the stirring occurs on the membrane, the stirring speed must be adjusted to ensure a proper homogenization without compromising membrane integrity. Likewise, a smooth PTFE coated stirring bar can be used to achieve optimal stirring while limiting membrane wear.

\section{The Vacuum Line and the Cold Trap}

The vacuum line connecting the space below the membrane to the ion source of the mass spectrometer is, together with the membrane, a key element to consider when optimizing the response time of the experimental setup. Because of high vacuum $\left(10^{-5}-10^{-8}\right.$ mbar) in the tubing, gases do not flow like a fluid but perform a random walk inside the tube towards the ion source of the mass spectrometer where gases are ionized. During their random walk, gases can adsorb and desorb at the surface of the tubing, thus slowing down the gas flow. The tubing length and cross-section should be optimized to increase the time response without compromising output signal of the mass spectrometer. Limiting length of the tubing decreases the response time of the system both because of limited inner tubing volume and decreased surface adsorption effects of the tubing. On the other hand, while small tubing cross-section favors the time response by limiting the tubing volume, this effect is counter-balanced by an increased probability of molecule absorption on the tubing surface, a too small cross-section decreasing the signal/noise ratio of the setup. We found an inner diameter of $1 / 4$ inch to be a good compromise for the type of experiments shown in this paper although smaller tubing down to $1 / 16$ inch can be suitably used (Konermann et al., 2008).

To limit water vapor entering the mass spectrometer ion source, the vacuum line tubing passes through a cold trap where the water vapor is condensed. Since the cold trap can also condense other gases, the choice of the trap temperature depends on the gas species to be analyzed. For example, cooling the vacuum line with liquid nitrogen $(77 \mathrm{~K})$ allows efficiently trapping water but also $\mathrm{CO}_{2}$ (Figure 3). The condensation points of other main gases $\left[\mathrm{N}_{2}, \mathrm{O}_{2}\right.$, and argon $\left.(\mathrm{Ar})\right]$ are much lower than that of water and are usually hard to selectively trap (Figure 3). A temperature of $200 \mathrm{~K}$ allows selective trapping of water and can be obtained using a mix of ethanol and dry ice in the absence of a cooling unit (Bailleul et al., 2017). The cold trap should be situated as close as possible to the vacuum pump of the mass spectrometer in order to keep its internal pressure as low as possible and limit unintended trapping. For further information on optimization of 


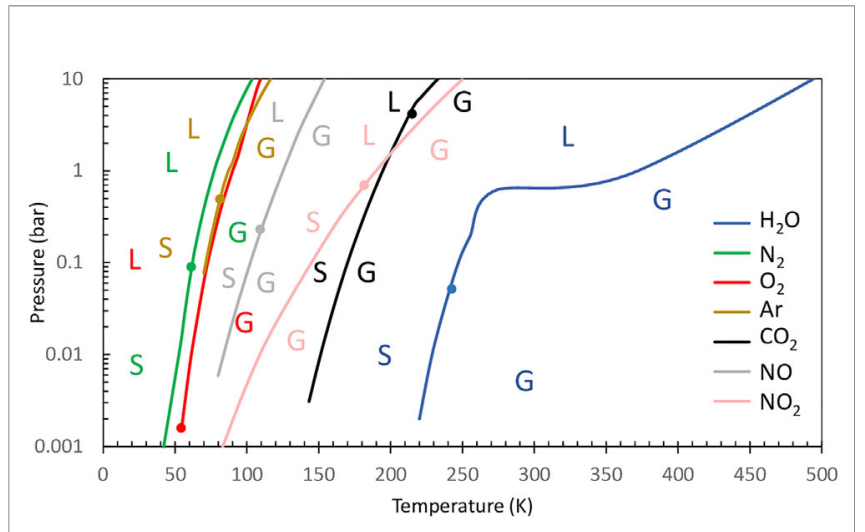

FIGURE 3 | Phase diagram of some gas components of the Earth's atmosphere. Shown are graphical views of the vapor-liquid and vapor-solid border $\mathrm{H}_{2} \mathrm{O}, \mathrm{N}_{2}, \mathrm{O}_{2}, \mathrm{Ar}, \mathrm{CO}_{2}, \mathrm{~N}_{2} \mathrm{O}$, and $\mathrm{NO}$. Dots represent triple points. Letters are placed on the side of the phase diagram, representing gas phase $(\mathrm{G})$, solid phase $(\mathrm{S})$, and liquid phase $(\mathrm{L})$. Shown are data from the gas encyclopedia, Air Liquide, 1976 more data can be found at https:// encyclopedia.airliquide.com/.

the membrane inlet system, readers are referred to (Konermann et al., 2008; Beckmann et al., 2009; Shevela et al., 2018).

\section{Mass Spectrometer}

Mass spectrometry is a technique that allows separation and detection of charged molecules in a gas phase depending on their mass over charge $(\mathrm{m} / \mathrm{z})$ ratio. During ionization, most reactions produce a single positively charged ion. But most often, the molecule is broken down by ionization, and seldom, double ionization can occur; these effects give rise to two or more fragments. The fragmentation pattern is a signature of the molecule and depends on the ionization method used. In the case of small molecules like gases, the main ion (molecular ion) results from the loss of an electron, other fragments representing a minor part in the fragmentation pattern (Table 1). The mass spectrometer, by measuring the signal intensity of detected ions for $\mathrm{m} / \mathrm{z}$ of interest, enables the determination of gas amounts (Methods S1). Any mass spectrometer can be used in a MIMS setup with various ion sources (e.g. pulsed ionization, glow discharged ionization) and analyzers (e.g. Time Of Flight, Ion Trap) (Johnson et al., 2000). However, magnetic sector or quadrupole mass spectrometers are the most commonly used for gas analysis in a MIMS setup, although quadrupole has the advantage of portability and low price (Ferrón et al., 2016; Bailleul et al., 2017; Chatton et al., 2017).

\section{Data Management}

Because the mass spectrometer is consuming gases, measured variations of gas concentrations must be corrected from the mass spectrometer consumption to determine actual gas exchange rates between the biological sample and the extracellular medium (Methods S2). Although this effect has been well described (Berlier et al., 1985; Kotiaho and Lauritsen, 2002; Konermann et al., 2008) its correction has been overlooked in the recent literature. After calculating gas concentrations inside
TABLE 1 | Typical mass fragmentation pattern of various gases.

\begin{tabular}{|c|c|c|c|c|c|c|c|c|c|}
\hline & $H_{2}$ & $D_{2}$ & $\mathrm{H}_{2} \mathrm{O}$ & $N_{2}$ & NO & $\mathrm{O}_{2}$ & $A r$ & $\mathrm{CO}_{2}$ & $\mathrm{~N}_{2} \mathrm{O}$ \\
\hline Nominal m/z & 2 & 4 & 18 & 28 & 30 & 32 & 40 & 44 & 44 \\
\hline 1 & 2 & & & & & & & & \\
\hline 2 & 100 & 1.59 & & & & & & & \\
\hline 4 & & 100 & & & & & & & \\
\hline 12 & & & & & & & & 8.71 & \\
\hline 14 & & & & 13.79 & 7.51 & & & & 12.91 \\
\hline 15 & & & & & 2.4 & & & & 0.1 \\
\hline 16 & & & 0.9 & & 1.5 & 21.8 & & 9.61 & 5 \\
\hline 17 & & & 21.22 & & & & & & \\
\hline 18 & & & 100 & & & & & & \\
\hline 19 & & & 0.5 & & & & & & \\
\hline 20 & & & & & & & 14.62 & & \\
\hline 22 & & & & & & & & 1.9 & \\
\hline 28 & & & & 100 & & & & 9.81 & 10.81 \\
\hline 29 & & & & 0.74 & & & & 0.1 & 0.1 \\
\hline 30 & & & & & 100 & & & & 31.1 \\
\hline 31 & & & & & 0.4 & & & & \\
\hline 32 & & & & & 0.2 & 100 & & & \\
\hline 36 & & & & & & & 0.3 & & \\
\hline 38 & & & & & & & 0.05 & & \\
\hline 40 & & & & & & & 100 & & \\
\hline 44 & & & & & & & & 100 & 100 \\
\hline 45 & & & & & & & & 1.2 & 0.07 \\
\hline 46 & & & & & & & & 0.4 & \\
\hline
\end{tabular}

For each gas, shown is the relative amount of $m / z$ in percentage of the maximal signal. Data are extracted from https://webbook.nist.gov/chemistry/. Fragmentations patterns are here given for natural isotopic abundance and therefore include isotopes-specific signal (e.g. $\mathrm{m} / \mathrm{z}=45$ for $\mathrm{CO}_{2}$ reflects natural abundance of ${ }^{13} \mathrm{CO}_{2}$ ). Note that the exact fragmentation patterns depend on each ion source and the ionization energy used and must be determined for each instrument.

the reaction vessel, gas exchange rates are calculated by correcting from the mass spectrometer consumption. Fluctuations of physical properties of the setup can result in variations of the flux of gas to the mass spectrometer and be an important source of noise. An additional normalization of gas exchange rates to a non-reactive gas (like $\mathrm{N}_{2}$ or Ar) can advantageously correct such signal shifts or noise. These artifacts are therefore highly limited although biggest ones remain (Figure S2). Note that prior to any experiment, one must ensure the absence of gas leakage in the system (tubing, connections, inlets), which can be done by flushing helium outside the setup and following the $\mathrm{m} / \mathrm{z}=4$ with the mass spectrometer. Details of the calculations have been described in Methods $\mathbf{S 1}$ and S2, and we have developed easy-to-run software that allows real time calculation and visualization of MIMS data (Downloadable at: https://github.com/francoisBurlacot/MIMS_Analysis).

\section{MIMS USAGE IN ALGAL RESEARCH}

MIMS has been initially developed and is still widely used to measure oxygen exchange during photosynthesis. Its usage has been extended to the study of other cellular mechanisms, such as hydrogen production, carbon concentrating mechanisms, and more recently, nitric oxide (NO) photoreduction into $\mathrm{N}_{2} \mathrm{O}$. We hereby provide some examples of applications of the MIMS in the field of algal biology to measure gas exchanges in the model species Chlamydomonas reinhardtii (Figure 4). 


\section{Assessment of Photosynthetic Oxygen Exchange}

By using ${ }^{18} \mathrm{O}$-enriched $\mathrm{O}_{2}$ in illuminated microalgal suspension, Hoch and Kok (Hoch and Kok, 1963) could show that $\mathrm{O}_{2}$ can be both produced and consumed during photosynthesis. While $\mathrm{O}_{2}$ is produced by PSII from water splitting, $\mathrm{O}_{2}$ is simultaneously consumed by different cellular processes (Figures 4 and $\mathbf{5 A}$ ). Practically, the use of highly enriched $\mathrm{O}_{2}$ (usually around $99 \%$ ${ }^{18} \mathrm{O}$ ) allows neglecting ${ }^{18} \mathrm{O}^{16} \mathrm{O}$ species, thus measurements of ${ }^{16} \mathrm{O}^{16} \mathrm{O}(\mathrm{m} / \mathrm{z}=32)$ and ${ }^{18} \mathrm{O}^{18} \mathrm{O}(\mathrm{m} / \mathrm{z}=36)$ are used to determine rates of gross $\mathrm{O}_{2}$ evolution $\left(\mathrm{O}_{2}\right.$ Evolution $)$ and $\mathrm{O}_{2}$ uptake $\left(\mathrm{O}_{2}\right.$ Uptake), net $\mathrm{O}_{2}$ production rate $\left(\mathrm{Net} \mathrm{O}_{2}\right)$ being the end result of $\mathrm{O}_{2}$ Evolution and Uptake. Considering that water splitting only produces ${ }^{16} \mathrm{O}_{2}$ (the natural abundance of ${ }^{16} \mathrm{O}$ being $99.8 \%, \mathrm{O}_{2}$ is produced from $\mathrm{H}_{2} \mathrm{O}$ at $99.6 \%$ as ${ }^{16} \mathrm{O}_{2}$ ) and neglecting isotopic discrimination between ${ }^{18} \mathrm{O}_{2}$ and ${ }^{16} \mathrm{O}_{2}$ by uptake mechanisms, the following equations modified from (Radmer and Kok, 1976; Peltier and Thibault, 1985b) can be used:

$$
\begin{gathered}
\mathrm{O}_{2} \quad \text { Uptake }=v^{18} \mathrm{O}_{2} \times\left(1+\frac{C_{18} \mathrm{O}_{2}}{{ }_{{ }^{18} \mathrm{O}_{2}}(t)}\right) \\
\mathrm{O}_{2} \quad \text { Evolution }=v^{16} \mathrm{O}_{2}-v^{18} \mathrm{O}_{2} \times \frac{C_{16} \mathrm{O}_{2}}{{ }^{{ }^{18} \mathrm{O}_{2}}(t)}
\end{gathered}
$$

$$
\text { Net } \mathrm{O}_{2}=\mathrm{O}_{2} \quad \text { Evolution }+\mathrm{O}_{2} \quad \text { Uptake }
$$

where $v_{18} \mathrm{O}_{2}$ and $v_{16} \mathrm{O}_{2}$ are the gas exchange rates of ${ }^{18} \mathrm{O}_{2}$ and ${ }^{16} \mathrm{O}_{2}$ respectively; $\mathrm{C}_{18} \mathrm{O}_{2}(t)$ and $\mathrm{C}_{16} \mathrm{O}_{2}(t)$ represent the gas concentrations of ${ }^{18} \mathrm{O}_{2}$ and ${ }^{16} \mathrm{O}_{2}$ respectively (see Methods $\mathbf{S} 1$ and S2). Typical patterns of ${ }^{18} \mathrm{O}_{2}$ and ${ }^{16} \mathrm{O}_{2}$ concentration, gross $\mathrm{O}_{2}$ evolution, $\mathrm{O}_{2}$ uptake, and $\mathrm{O}_{2}$ net production rates as well as cumulated $\mathrm{O}_{2}$ exchanges measured in C. reinhardtii cells during a dark to light transient are shown in Figures 5B-D.

Measuring $\mathrm{O}_{2}$ exchange by MIMS in microalgae and cyanobacteria allowed dissecting molecular players involved in the $\mathrm{O}_{2}$ uptake process, initially by using various inhibitors or characterizing the dependency on $\mathrm{O}_{2}$ or $\mathrm{CO}_{2}$ concentrations (Badger et al., 2000). (Radmer and Kok, 1976) early proposed that a highly efficient $\mathrm{O}_{2}$ photoreduction process was present in cyanobacteria and microalgae. The persistence of mitochondrial respiration in the light was shown to contribute (Peltier and Thibault, 1985b), and the existence of a $\mathrm{CO}_{2}$-dependent $\mathrm{O}_{2}$ uptake component was evidenced (Badger, 1985; Sültemeyer et al., 1987). With the development of genetic approaches, the nature and contribution of the different players were better characterized. For example, the contribution of mitochondrial respiration to $\mathrm{O}_{2}$ uptake is enhanced in the absence of the proton gradient regulation like 1 (PGRL1)-mediated cyclic electron flow (CEF), thus showing the functional complementarity between these pathways in the production of intra-cellular ATP (Dang et al., 2014). Redox communication between chloroplast and

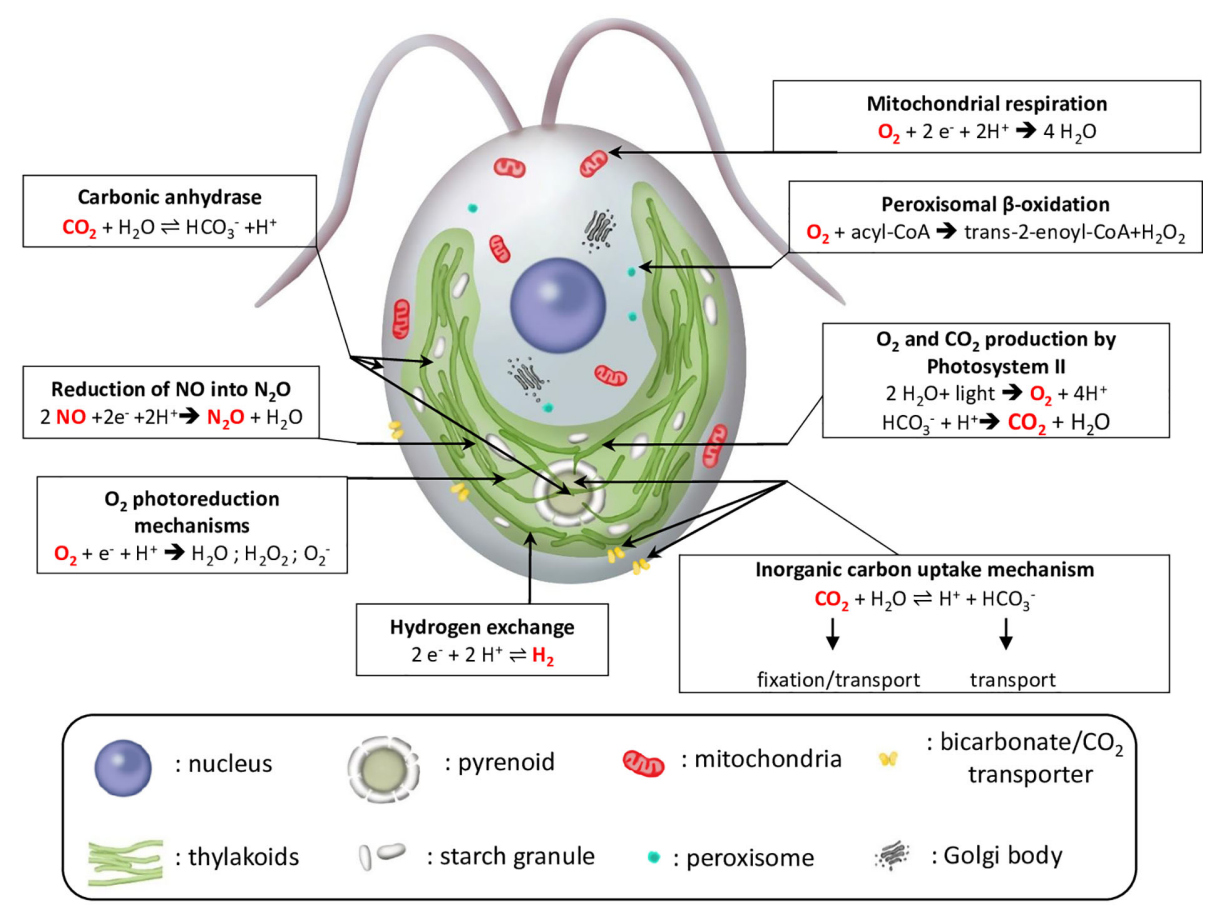

FIGURE 4 | Schematic view of major reactions involving gas exchange in microalgae illustrated for $C$. reinhardtii. Arrows indicate the subcellular localization of the different reactions. For each reaction, gas species that can be measured by MIMS are in red. ADP, adenosine diphosphate; acyl-CoA, acyl-Coenzyme A; ${ }^{-}$, reducing equivalent; trans-2-enoyl-CoA, trans-2,3-dehydroacyl-Coenzyme A. 
A

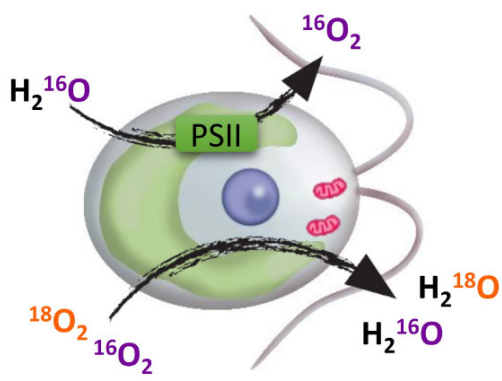

C

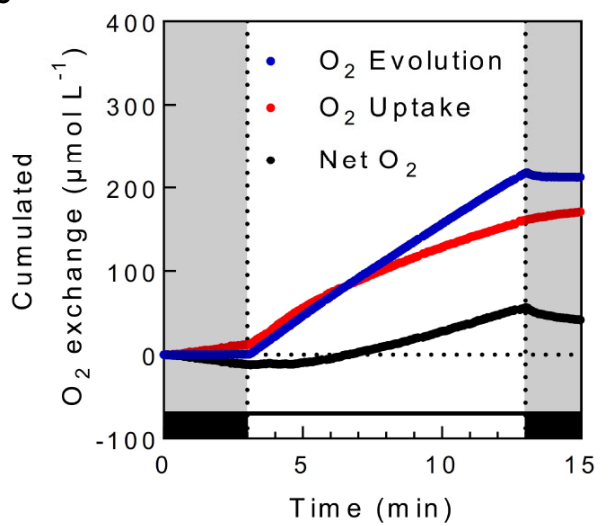

B

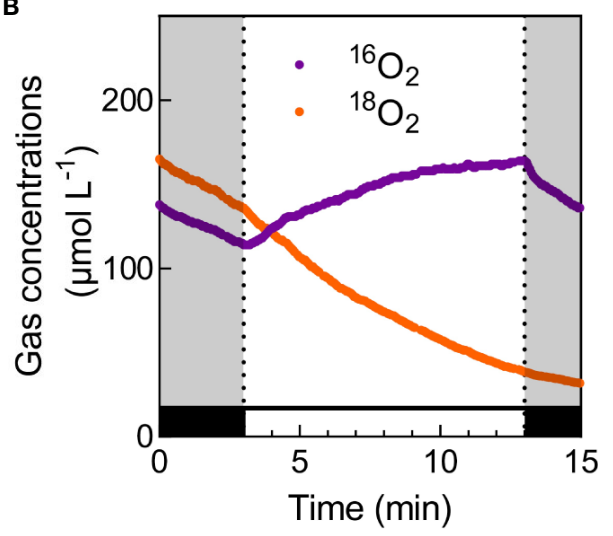

D

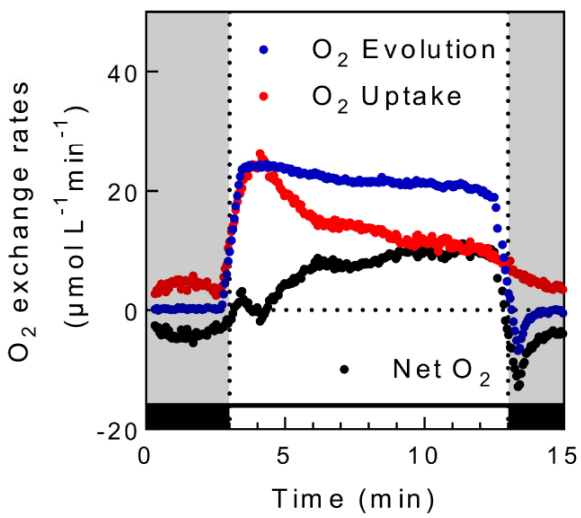

FIGURE 5 | In vivo measurements of photosynthetic $\mathrm{O}_{2}$ exchange in the presence of ${ }^{18} \mathrm{O}$-labeled $\mathrm{O}_{2}$. (A). Schematic view of oxygen exchange illustrated in $\mathrm{C}$. reinhardtii. While photosystem II (PSII) produces unlabeled $\mathrm{O}_{2}$ from the photolysis of $\mathrm{H}_{2} \mathrm{O}$, oxygen uptake mechanisms consume both ${ }^{18} \mathrm{O}-$ labeled and unlabeled $\mathrm{O}_{2}$ (B) ${ }^{16} \mathrm{O}_{2}$ and ${ }^{18} \mathrm{O}_{2}$ concentrations measured in C. reinhardtii cells during dark-light transients. (C, D). Calculated cumulated $\mathrm{O}_{2}$ exchanges (C) and the corresponding $\mathrm{O}_{2}$ exchange rates (D) for the same experiment. Cells were grown photoautotrophically in air, centrifuged and resuspended in fresh medium at a concentration of 20

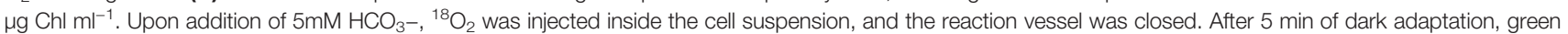
light was turned on $\left(500 \mu \mathrm{mol}\right.$ photon $\left.\mathrm{m}^{-2} \mathrm{~s}^{-1}\right)$ for $10 \mathrm{~min}$. Levels of ${ }^{16} \mathrm{O}_{2}$ and ${ }^{18} \mathrm{O}_{2}$ were recorded at respective $\mathrm{m} / \mathrm{z}=32$ and $36 . \mathrm{O}_{2}$ Uptake (red), $\mathrm{O}_{2}$ Evolution (blue), and $\mathrm{Net}_{2}$ production (black) were calculated as described; cumulated gas exchange were calculated by directly integrating obtained exchange rates. To limit noise on the exchange rates graphic, data shown in (D) are integrated with a sliding average of $30 \mathrm{~s}$ wide.

peroxisome (Kong et al., 2018) or with mitochondria in diatoms (Bailleul et al., 2015) was also evidenced from $\mathrm{O}_{2}$ exchange measurements. The involvement of Flavodiiron proteins (Flvs) in light-dependent $\mathrm{O}_{2}$ uptake was further established in cyanobacteria (Helman et al., 2003; Allahverdiyeva et al., 2013), and more recently in microalgae (Chaux et al., 2017). MIMS is nowadays widely used to understand the fate of the photosynthetic electron flow in various environmental conditions and mutant of cyanobacteria (Ermakova et al., 2016; Boatman et al., 2018; Luimstra et al., 2019), microalgae (Fisher and Halsey, 2016), or coral reef symbiosis (Einbinder et al., 2016).

If laboratory studies performed on model species allowed recognizing $\mathrm{O}_{2}$ photoreduction as a major alternative photosynthetic electron sink crucial for cell acclimation to various environmental conditions (Curien et al., 2016), the relative contribution of different $\mathrm{O}_{2}$ uptake mechanisms in natural environments remains largely unexplored (Bailleul et al., 2017). Despite its performance in measuring gross photosynthesis, MIMS has long remained a cumbersome technique, not suitable for field experiments. On the other hand, chlorophyll fluorescence measurements using pulseamplitude modulated (PAM) fluorimeter have been widely used for estimating PSII yield in natural environments such as in the ocean (Falkowski and Kolber, 1995). Chlorophyll fluorescence however, faces some limitations when used to determine gross $\mathrm{O}_{2}$ production since the estimation of electron transport rates requires the measurement of cell absorbance (Genty et al., 1989; Godaux et al., 2015), which is difficult to realize in outdoor conditions. Recently, the miniaturization of mass spectrometers allowed in situ measurements of $\mathrm{O}_{2}$ exchange in phytoplankton from the north Pacific (Ferrón et al., 2016) or in planktonic blooms from the north Atlantic (Bailleul et al., 2017), starting thus a new era for expanding research obtained in the laboratory on model species to species in their natural environments.

Indeed, fluorescence measurements have often been used together with MIMS $\mathrm{CO}_{2}$ and $\mathrm{O}_{2}$ exchange measurements to 
study the link between $\mathrm{CO}_{2}$ fixation and non-photochemical quenching of chlorophyll fluorescence (Sültemeyer et al., 1989; Fratamico et al., 2016; Ware et al., 2020). Furthermore, in conditions where the use of ${ }^{18} \mathrm{O}_{2}$ is not possible (e.g. anaerobiosis), coupling PSII quantum yield with gas exchanges has recently allowed determining gross $\mathrm{O}_{2}$ production and inferring the existence of an $\mathrm{O}_{2}$ uptake process (Burlacot et al., 2018).

\section{Hydrogen Production and Hydrogenase Activity Measurements}

In microalgae and cyanobacteria, hydrogenases $\left(\mathrm{H}_{2}\right.$ ases $)$ catalyze the reversible formation of hydrogen $\left(\mathrm{H}_{2}\right)$ by direct reduction of protons $\left(\mathrm{H}^{+}\right)$. In microalgae, the electron donor to the $[\mathrm{Fe}-\mathrm{Fe}]$ $\mathrm{H}_{2}$ ase is ferredoxin (Florin et al., 2001), which can be reduced by the photosynthetic electron transport chain or by fermentative pathways (Catalanotti et al., 2013). Experimentally, $\mathrm{H}_{2}$ production can be measured by different techniques, including modified $\mathrm{O}_{2}$ electrodes (Wang, 1980; Godaux et al., 2015), gas chromatography (Hunt and Smith, 1961; Nagy et al., 2018), nuclear magnetic resonance spectroscopy (NMR) (Xu et al., 2016; Manz et al., 2017), or MIMS. Among these techniques, MIMS and modified $\mathrm{O}_{2}$ electrodes allow in vivo quantitative measurement of hydrogen in a time-resolved manner. Under natural conditions, hydrogen photoproduction by microalgae is a transient phenomenon, generally considered as a safety valve avoiding over-reduction of PSI electron acceptors under anaerobiosis (Ghysels et al., 2013). Hydrogen photoproduction is limited by the $\mathrm{O}_{2}$ sensitivity of $\mathrm{H}_{2}$ ase, $\mathrm{O}_{2}$ being produced by PSII during illumination (Erbes et al., 1979). When using experimental conditions maintaining anaerobic conditions (thus limiting the $\mathrm{H}_{2}$ ase inhibition) like sulfur deprivation (Melis et al., 2000), low illumination (Liran et al., 2016) or $\mathrm{O}_{2}$ quenchers like glucose and glucose oxidase/ catalase (Godaux et al., 2015), a limitation of the supply of electrons to the $\mathrm{H}_{2}$ ase can be evidenced. The use of MIMS and of various C. reinhardtii mutants allowed identifying biological bottlenecks limiting the supply of electrons to the $\mathrm{H}_{2}$ ase (Tóth and Yacoby, 2019; Burlacot et al., 2020a). Lately, MIMS was used in the development of a very promising $\mathrm{H}_{2}$ photoproducing protocol using flashing light as the light source in photoautotrophic selfanaerobic conditions (Kosourov et al., 2018).

MIMS has early been used for in vitro and in vivo measurements of $\mathrm{H}_{2}$ ase activity (Jouanneau et al., 1980; Vignais et al., 1982; Berlier et al., 1985). In the presence of $\mathrm{H}_{2}, \mathrm{H}_{2}$ ase spontaneously splits $\mathrm{H}_{2}$ (Hoberman and Rittenberg, 1943; Rittenberg and Krasna, 1955), forming one proton with the reversible reaction:

$$
H y d+H_{2} \rightleftharpoons H y d: H^{-}+H^{+}
$$

where Hyd is the binding site of $\mathrm{H}_{2}$ ase. When supplying deuterium $\left(D_{2}\right), H D$ is formed during the back reaction (6) in the presence of protons in the reaction mixture:

$$
H y d: D^{-}+H^{+} \rightleftharpoons H y d+H D
$$

This reaction directly depends on the turnover rate of $\mathrm{H}_{2}$ ases (i.e. $\mathrm{H}_{2}$ ase activity) (Vignais, 2005). In the absence of $\mathrm{H}_{2}$ production or uptake, following kinetics of $\mathrm{D}_{2}, \mathrm{HD}$ and $\mathrm{H}_{2}$ with MIMS allows measuring the $\mathrm{H}_{2}$ ase activity ( $\mathrm{H}_{2}$ ase activity) by the $\mathrm{H} / \mathrm{D}$ exchange rate $\left(\mathrm{V}_{\text {exch }}\right)$ :

$$
H_{2} \text { ase activity }=V_{\text {exch }}(t)=\frac{1}{\tau}\left(2 v_{H_{2}}(t)+v_{H D}(t)\right)
$$

with

$$
\tau=\frac{C_{D_{2}}(t)+\frac{C_{H D}(t)}{2}}{C_{D_{2}}(t)+C_{H_{2}}(t)+C_{H D}(t)}
$$

where $C_{D_{2}}(t), C_{H_{2}}(t)$ and $C_{H D}(t)$ are the concentrations of $\mathrm{D}_{2}, \mathrm{H}_{2}$ and $\mathrm{HD}$ respectively and $v_{\mathrm{H}_{2}}(t), v_{H D}(t)$ being the gas exchange rates of $\mathrm{H}_{2}$ and $\mathrm{HD}$, respectively (see Methods $\mathrm{S1}$ and S2) (Cournac et al., 2004). A few microalgal species such as $C$. reinhardtii harbor $\mathrm{H}_{2}$ ases (Burlacot and Peltier, 2018) under anaerobic conditions. Measuring the H/D exchange allowed monitoring of $\mathrm{H}_{2}$ ase induction or inhibition in vivo (Vignais et al., 2002; Tolleter et al., 2011; Burlacot et al., 2018). Typical patterns of $\mathrm{D}_{2}, \mathrm{H}_{2}$ and $\mathrm{HD}$ exchange measured upon injection of $\mathrm{D}_{2}$ before and after induction of $\mathrm{H}_{2}$ ase in C. reinhardtii are shown on Figure 6. Note that in conditions where $\mathrm{H}_{2}$ ase produces $\mathrm{H}_{2}$ during illumination the $\mathrm{H}_{2}$ ase activity, needs to be corrected from the increase in total hydrogen species $\left(\mathrm{H}_{2}, \mathrm{HD}\right.$, $\mathrm{D}_{2}$ ) (Cournac et al., 2004). Although gas chromatography or NMR has also the potential to differentiate $\mathrm{D}_{2}, \mathrm{HD}$ and $\mathrm{H}_{2}$ (Hunt and Smith, 1961; Xu et al., 2016), MIMS allows performing such measurements in vitro and in vivo in a time resolved manner. If H/D exchange measurements using a MIMS allow determining the catalytic constant of $\mathrm{H}_{2}$ ase, it can also be used to determine the resistance of gas diffusion between the active $\mathrm{H}_{2}$ ase site and the reaction medium in vitro (Leroux et al., 2008). In vitro $\mathrm{H} / \mathrm{D}$ exchange measurements have been used to study enzymatic properties of native $\mathrm{H}_{2}$ ase (Abou Hamdan et al., 2012; Gauquelin et al., 2018), including $\mathrm{O}_{2}$-tolerant $\mathrm{H}_{2}$ ases (Liebgott et al., 2011), as well as $\mathrm{H}_{2}$ ases modified by site-directed mutagenesis in order to limit $\mathrm{O}_{2}$ diffusion to the active site (Cano et al., 2014). $\mathrm{H}_{2}$ photoproduction by microorganisms has recently regained huge interest for biofuel production due to recent improvements in strains and experimental protocols (Tóth and Yacoby, 2019). The use of MIMS should help in evaluating the upcoming combination of newly developed $\mathrm{H}_{2}$ production protocols (Kosourov et al., 2018; Nagy et al., 2018) and previously characterized mutants photoproducing more $\mathrm{H}_{2}$ (Tolleter et al., 2011; Eilenberg et al., 2016; Burlacot et al., 2018; Ben-Zvi et al., 2019). This has recently started using $f l v$ mutants (Jokel et al., 2019) and is promising for future bio $\mathrm{H}_{2}$ production developments.

\section{Assessing $\mathrm{NO}$ and $\mathrm{N}_{2} \mathrm{O}$ Gas Exchange}

On Earth, $6 \%$ of the radiative forcing is due to $\mathrm{N}_{2} \mathrm{O}$ (IPCC, 2013), whose greenhouse effect is 300 times that of $\mathrm{CO}_{2} \cdot \mathrm{N}_{2} \mathrm{O}$ is produced from the reduction of nitric oxide (NO) by bacteria (Goreau et al., 1980), fungi (Maeda et al., 2015), and microalgae (Guieysse et al., 2013). The measurement of $\mathrm{N}_{2} \mathrm{O}$ in a time resolved manner can help understand the dynamics of $\mathrm{N}_{2} \mathrm{O}$ 
A

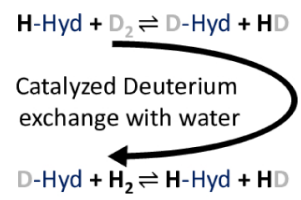

Chloroplast

B

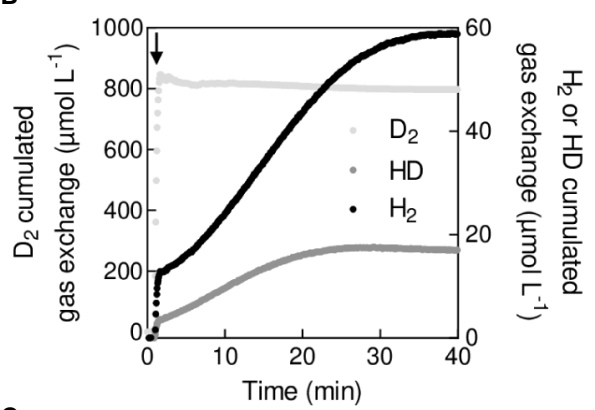

C

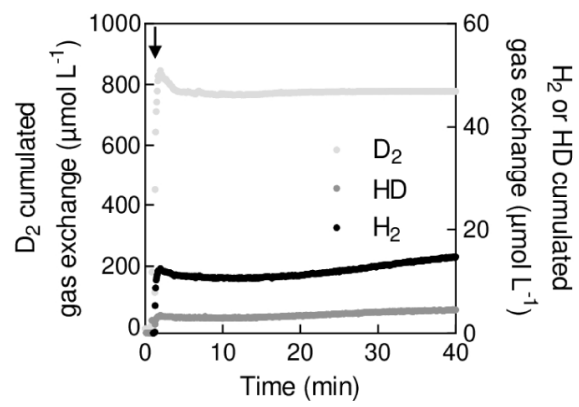

FIGURE 6 | In vivo measurement of the hydrogenase activity by H/D exchange (A). Principle of $H / D$ exchange. In the presence of labeled hydrogen $\left(D_{2}\right)$, the labeled deuterium $\left(\mathrm{D}^{+}\right)$is exchanged with protons $\left(\mathrm{H}^{+}\right)$at the catalytic site of $\mathrm{H}_{2}$ ase (-Hyd). (B). Cumulated gas exchange of $D_{2}, H D$, and $\mathrm{H}_{2}$ in wild type cells after $1 \mathrm{~h}$ anaerobiosis with induced hydrogenase. (C). Cumulated gas exchange of $D_{2}, H D$, and $H_{2}$ in wild type cells after 1 min of anaerobiosis without induction of hydrogenase. For (B, C), cell suspension of $C$. reinhardtii was maintained in anaerobiosis for $1 \mathrm{~min}$ (B) or $1 \mathrm{~h}$ (C) before $\mathrm{t}=0$. At $\mathrm{t}=1$ min (black arrow), $\mathrm{D}_{2}$ was bubbled for a few seconds before the reaction vessel was closed and H/D exchange recorded.

formation in the environment or in isolated organisms. In green microalgae, MIMS has recently been used to dissect the molecular mechanisms involved in the conversion of $\mathrm{NO}$ into $\mathrm{N}_{2} \mathrm{O}$ (Figure 7) (Burlacot et al., 2020b). In practical terms, the detection of $\mathrm{N}_{2} \mathrm{O}$ requires specific calculations because its mass spectrum overlaps that of $\mathrm{CO}_{2}$ (see Methods S1). However, due to a relatively high detection limit for $\mathrm{N}_{2} \mathrm{O}$ (around $18 \mu \mathrm{M}$ ) (Chatton et al., 2017), MIMS is not suitable for detecting low $\mathrm{N}_{2} \mathrm{O}$ amounts, such as in water in equilibrium with ambient air (4.3 $\mu \mathrm{M})$ (IPCC, 2013).

$\mathrm{NO}$ is an important intracellular signaling molecule in algae like in most living organisms. While NO is crucial for growth of C. reinhardtii under anaerobiosis and for its acclimation to nitrogen, sulfur or phosphate deprivation (Hemschemeier et al., 2013; Wang and Spalding, 2014; De Mia et al., 2019;
Filina et al., 2019), mechanisms of NO production remain blurry. The use of MIMS in algae fed with nitrates or nitrites, allowed to evidence the role of $\mathrm{NO}$ reduction mechanisms in the regulation of NO homeostasis (Burlacot et al., 2020b). Following NO production can also be based on imaging fluorescent chemical probes specifically reacting with NO ( $\mathrm{Li}$ and Wan, 2015) or on the use of specific electrodes (Csonka et al., 2015). However, MIMS by supplying quantitative, time resolved, and stable measurements of NO (Bethke et al., 2004; Conrath et al., 2004), with further simultaneous measurement of $\mathrm{NO}$ reduction products such as $\mathrm{N}_{2} \mathrm{O}$, should help deciphering mechanisms participating in NO homeostasis.

\section{Inorganic Carbon Affinity in Microalgae and Carbonic Anhydrase Activity}

When grown under low $\mathrm{CO}_{2}$ concentration, many microalgae or cyanobacteria induce an active import of inorganic carbon $\left(\mathrm{C}_{\mathrm{i}}=\right.$ $\mathrm{CO}_{2}$ and $\mathrm{HCO}_{3}{ }^{-}$) (Figure 8A) from the extracellular medium to the active site of $\mathrm{CO}_{2}$ fixation (Badger et al., 1980; Badger and Andrews, 1982; Sültemeyer et al, 1991; Giordano et al., 2005; Reinfelder, 2011). This mechanism, called Carbon Concentrating Mechanism (CCM), principally operates by concentrating $\mathrm{HCO}_{3}{ }^{-}$inside cells (Price et al., 2007). In microalgae, $\mathrm{HCO}_{3}{ }^{-}$ is converted into $\mathrm{CO}_{2}$ inside the pyrenoid, at the vicinity of the carbon-fixing enzyme (RuBisCO) thus increasing the local $\mathrm{CO}_{2}$

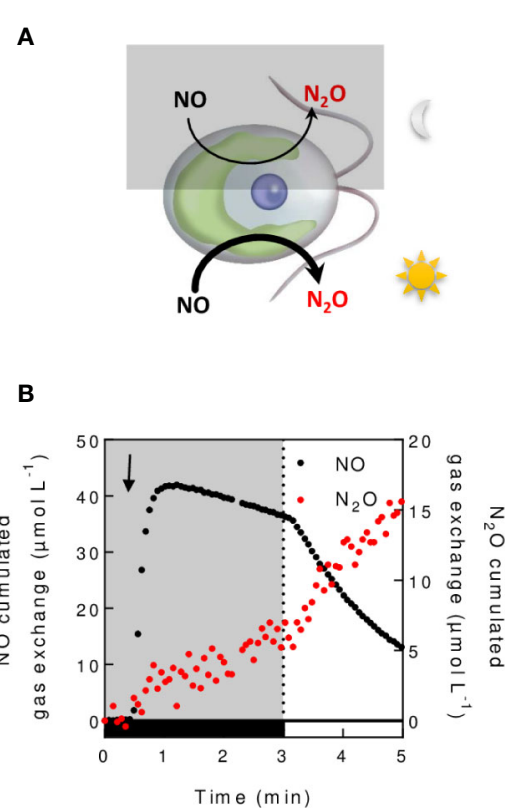

FIGURE 7 | In vivo measurement of $\mathrm{NO}$ reduction into $\mathrm{N}_{2} \mathrm{O}$. (A). Schematic $\mathrm{N}_{2} \mathrm{O}$ production mechanisms illustrated in C. reinhardtii. Nitric oxide (NO) is reduced in the chloroplast both in a light dependent and independent manner (Burlacot et al., 2020b). (B). Cumulated gas exchange of $\mathrm{NO}$ and $\mathrm{N}_{2} \mathrm{O}$ in C. reinhardtii cells grown autotrophically ( $100 \mu \mathrm{g}$ chlorophyll. $\left.\mathrm{ml}^{-1}\right)$ during a dark to light transition. Glucose oxidase/catalase and glucose are added to the algal suspension to reach anaerobiosis. After injection of a NO-saturated water solution in the cell suspension (black arrow), $\mathrm{NO}$ and $\mathrm{N}_{2} \mathrm{O}$ exchange is measured as described in (Burlacot et al., 2020b). 
concentration (Figure 8A) (Mackinder, 2018). The CCM ensures high $\mathrm{C}_{\mathrm{i}}$ fixation rates by photosynthesis under low $\mathrm{C}_{\mathrm{i}}$ concentration (Badger et al., 1980). When active, the CCM results in an increased apparent affinity of photosynthesis for $\mathrm{C}_{\mathrm{i}}$, which can be assessed by measuring $\mathrm{O}_{2}$ production rates at various $\mathrm{C}_{\mathrm{i}}$ concentrations, either using an $\mathrm{O}_{2}$ electrode (Badger et al., 1980) or a MIMS (Sültemeyer et al., 1993). MIMS has the advantage of simultaneously measuring $\mathrm{O}_{2}$ and $\mathrm{CO}_{2}$. Since the $\mathrm{CO}_{2}$ decreases during the time course of the experiment due to the activity of photosynthesis, it is possible to determine in one single experiment net $\mathrm{O}_{2}$ or $\mathrm{CO}_{2}$ exchange rates at different $\mathrm{CO}_{2}$ concentrations $\left(v_{\mathrm{O}_{2}}\left(\mathrm{C}_{\mathrm{CO}_{2}}(t)\right)\right.$ or $\left.v_{\mathrm{O}_{2}}\left(C_{\mathrm{CO}_{2}}(t)\right)\right)$ during $\mathrm{CO}_{2}$ fixation by photosynthesis (Douchi et al., 2019). Figures 8B, C show typical experiments in which $\mathrm{CO}_{2}$ uptake and $\mathrm{O}_{2}$ production rates have been determined as a function of the $\mathrm{CO}_{2}$ concentration in air-grown and $\mathrm{CO}_{2}$-grown cells of $C$. reinhardtii. Note that in such experiments the cell concentration must be kept low enough to ensure that photosynthetic gas exchange kinetics are sufficiently slow as compared to the response time of the MIMS setup. Using this technique (Figure 8), the apparent affinity for $\mathrm{C}_{\mathrm{i}}$ of photosynthetic $\mathrm{O}_{2}$ production of cells with an active CCM is about 10 times higher than in cells with no active CCM as previously reported (Badger et al., 1980; Sültemeyer et al., 1998).

During the induction of CCM, carbonic anhydrases (CAs) are also induced and catalyze the reversible hydration of $\mathrm{CO}_{2}$ by water which is summarized in reaction (8):

$$
\mathrm{CO}_{2}+\mathrm{H}_{2} \mathrm{O} \rightleftharpoons \mathrm{HCO}_{3}^{-}+\mathrm{H}^{+}
$$

In microalgae, different CA isoforms are present in the different cellular compartments, thus limiting the disequilibrium between transported and consumed $\mathrm{C}_{\mathrm{i}}$ species (Figure 4)

A
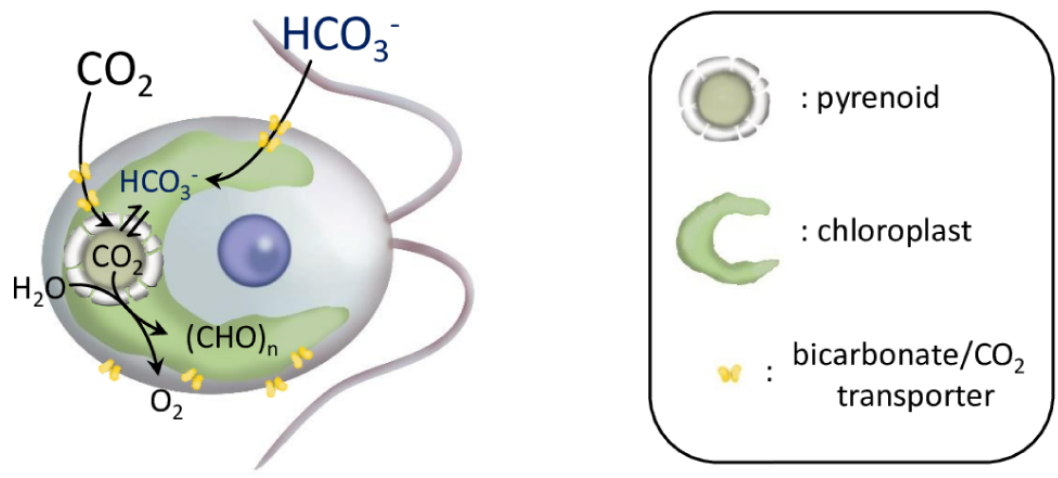

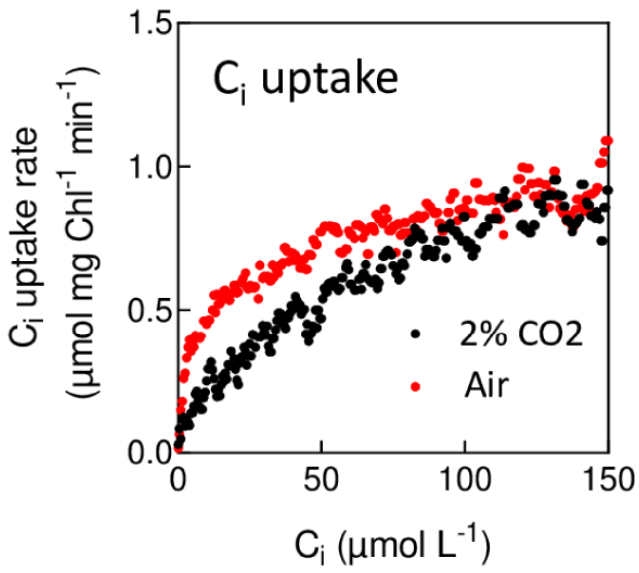

C

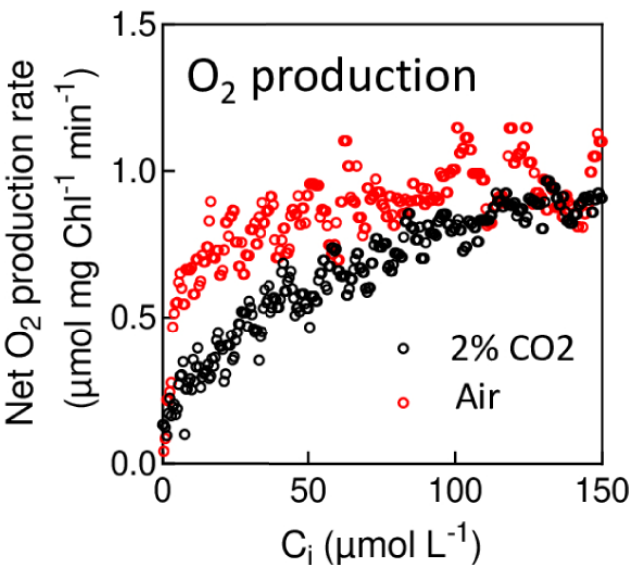

FIGURE 8 | In vivo measurement of the apparent affinity of photosynthesis for $\mathrm{CO}_{2}$ during the induction of the Carbon Concentrating Mechanisms. (A). Schematic view of the carbon transport mechanism in $\mathrm{C}$. reinhardtii. In the presence of a CCM, inorganic carbon $\left(\mathrm{C}_{i}\right)$ is actively transported, thus increasing the $\mathrm{CO}_{2}$ concentration at the $\mathrm{CO}_{2}$ fixation site. (B). $\mathrm{C}_{i}$ uptake rates measured at different $\mathrm{C}_{\mathrm{i}}$ concentrations during its depletion in $\mathrm{C}$. reinhardtii cells grown in $2 \% \mathrm{CO}_{2}$ in air (in red) or in air levels of $\mathrm{CO}_{2}$ (in black). (C). Net $\mathrm{O}_{2}$ production rates depending on $\mathrm{C}_{i}$ during the same experiments as in (B). C. reinhardtii cells were grown either at air level of $\mathrm{CO}_{2}$ or $2 \% \mathrm{CO}_{2}$, growing medium; cell sampling was the same as described in Figure 2. After sampling and resuspention in fresh medium, green saturating light $\left(3,000 \mu \mathrm{mol}\right.$ photon $\left.\mathrm{m}^{-2} \mathrm{~s}^{-1}\right)$ was turned on, and $\mathrm{O}_{2}$ production and $\mathrm{C}_{\mathrm{i}}$ uptake were recorded during the depletion of $\mathrm{C}_{i}$. With this technique, the apparent affinity for $\mathrm{C}_{i}$ of photosynthesis measured by net $\mathrm{O}_{2}$ production in cells with an active CCM $\left(\mathrm{K}_{1 / 2}=5 \mu \mathrm{M}\right)$ is 10 times higher than the one measured when the CCM is not induced $\left(K_{1 / 2}=50 \mu \mathrm{M}\right)$. 
(Sültemeyer et al., 1990; Mackinder et al., 2017). Inside the pyrenoid, CA rapidly converts $\mathrm{HCO}_{3}{ }^{-}$into $\mathrm{CO}_{2}$, the substrate of RuBisCO, thus ensuring a high $\mathrm{CO}_{2}$ concentration at the catalytic site of the enzyme (Mackinder, 2018).

When their CCM is active, cyanobacteria and microalgae can take both $\mathrm{CO}_{2}$ and $\mathrm{HCO}_{3}{ }^{-}$in the medium (Sültemeyer et al., 1991; Badger et al., 1994). A way to assess the net flux of both species is to use the disequilibrium between inorganic species (see equation 8) induced by the preferential uptake of one species. Note that this approach is not possible in the presence of extracellular CA, which has limited its usage in microalgae (Badger et al., 1994; Palmqvist et al., 1994). By comparing net $\mathrm{O}_{2}$ production (proportional to the overall net $C_{i}$ uptake) to the net
$\mathrm{CO}_{2}$ uptake and knowing the uncatalyzed rate of $\mathrm{CO}_{2}$ and $\mathrm{HCO}_{3}{ }^{-}$interconversion (8), it is possible to calculate the net $\mathrm{HCO}_{3}{ }^{-}$uptake (Badger et al., 1994). Using the disequilibrium method with MIMS has shown that $\mathrm{HCO}_{3}{ }^{-}$was preferentially taken during CCM in cyanobacteria (Sültemeyer et al., 1998).

In the presence of doubly ${ }^{18} \mathrm{O}$-labeled $\mathrm{CO}_{2}$, the $\mathrm{CA}$ activity which catalyzes the exchange of oxygen isotopes between $\mathrm{CO}_{2}$ and $\mathrm{H}_{2} \mathrm{O}$ results in a progressive dilution of ${ }^{18} \mathrm{O}$ from $\mathrm{CO}_{2}$ (Gerster, 1971) (Figure 9A). To limit the background level of $\mathrm{m} /$ $\mathrm{Z}=44\left({ }^{12} \mathrm{CO}_{2}\right)$ due to naturally present $\mathrm{CO}_{2}$ in the algal suspension, the assay can be done using ${ }^{18} \mathrm{O}$-enriched ${ }^{13} \mathrm{CO}_{2}$ (Radmer and Kok, 1976), following the $\mathrm{m} / \mathrm{z}=45\left({ }^{13} \mathrm{C}^{16} \mathrm{O}_{2}\right), 47$ $\left({ }^{13} \mathrm{C}^{18} \mathrm{O}^{16} \mathrm{O}\right)$ and $49\left({ }^{13} \mathrm{C}^{18} \mathrm{O}_{2}\right)$. After injection of ${ }^{13} \mathrm{C}^{18} \mathrm{O}_{2}$

A

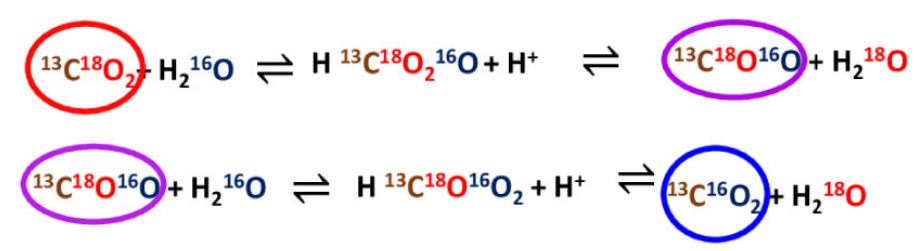

$\mathrm{CO}_{2}$ grown cells

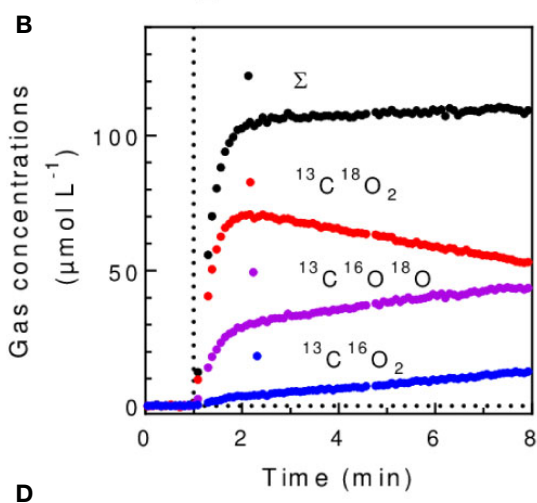

D

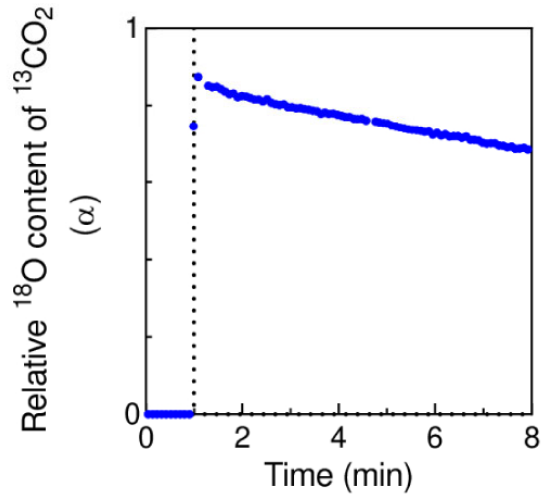

Air grown cells

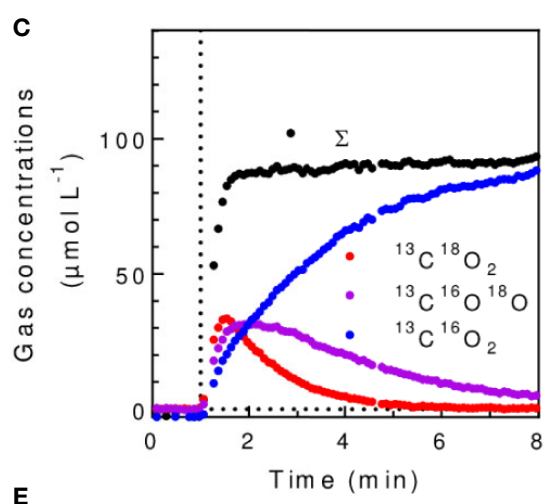

E

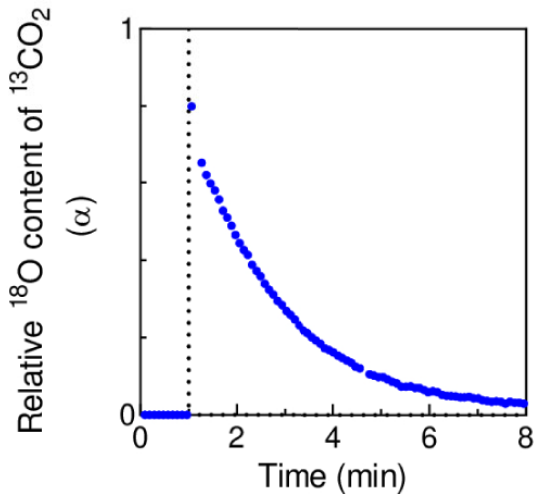

FIGURE 9 | In vivo measurement of carbonic anhydrase (CA) activity. (A). Cascade of reactions leading to the unlabeling of ${ }^{18} \mathrm{O}$-enriched $\mathrm{CO}_{2}$ in solution in $\mathrm{H}_{2} \mathrm{O}$. (B, C). Concentrations of ${ }^{13} \mathrm{C}^{16} \mathrm{O}_{2},{ }^{13} \mathrm{C}^{18} \mathrm{O}^{16} \mathrm{O},{ }^{13} \mathrm{C}^{18} \mathrm{O}_{2}$ and total ${ }^{13} \mathrm{C}$-labeled carbon form $(\Sigma)$ upon injection of ${ }^{13} \mathrm{C}^{18} \mathrm{O}_{2}$ in a suspension of $C$. reinhardtii cells cultured in $2 \% \mathrm{CO}_{2}$ (B) or at air level of $\mathrm{CO}_{2}$ (C). (D, E). Isotopic ${ }^{18} \mathrm{O}$ content $(\alpha)$ of ${ }^{13} \mathrm{CO}_{2}$ during experiments of (B, C) respectively. ${ }^{13} \mathrm{C}$ and ${ }^{18} \mathrm{O}$-enriched $\mathrm{CO}_{2}$ was used to avoid the mass spectrometric background on $\mathrm{m} / \mathrm{z}=44$ due to naturally present $\mathrm{CO}_{2}$, therefore enhancing the signal to background ratio (Radmer and $\mathrm{Kok}$, 1976). ${ }^{13} \mathrm{C}^{18} \mathrm{O}_{2}$ was injected after $1 \mathrm{~min}$ of darkness at $0.1 \mathrm{mM}$ final concentration (vertical dotted line). 
(supplied as $\mathrm{H}^{13} \mathrm{C}^{18} \mathrm{O}_{3}{ }^{-}$in a buffered reaction medium) a typical pattern of the progressive unlabeling of ${ }^{13} \mathrm{CO}_{2}$ in C. reinhardtii cells is shown (Figures 9B-E). The isotopic content of ${ }^{18} \mathrm{O}$ in ${ }^{13} \mathrm{CO}_{2}$ during the progressive unlabeling is given by:

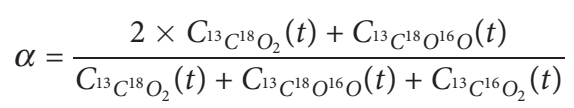

where $C_{13} \mathrm{C}^{18} \mathrm{O}_{2}(t), C_{13} \mathrm{C}^{18} \mathrm{O}^{16} \mathrm{O}(t)$ and $C^{13} \mathrm{C}^{16} \mathrm{O}_{2}(t)$ are the concentrations of ${ }^{13} \mathrm{C}^{18} \mathrm{O}_{2},{ }^{13} \mathrm{C}^{18} \mathrm{O}^{16} \mathrm{O}$ and ${ }^{13} \mathrm{C}^{16} \mathrm{O}_{2}$ respectively (Methods 1 ). On purified $\mathrm{CA}$, the isotopic enrichment decays exponentially:

$$
\alpha=a_{1} \times e^{-\theta t}
$$

where $\theta$ is the rate constant of the exchange of ${ }^{18} \mathrm{O}$ with water (Gerster, 1971; Silverman, 1982). Note that in some cases like a concomitant use of ${ }^{18} \mathrm{O}$-labeled $\mathrm{O}_{2}$, the presence of ${ }^{18} \mathrm{O}$ and $\mathrm{C}^{16} \mathrm{O}_{2}$ in the ion source of the mass spectrometer can spontaneously generate $\mathrm{C}^{18} \mathrm{O}^{16} \mathrm{O}$ which needs to be corrected (Cournac et al., 1993). In vivo, a CA isotope exchange assay measures the global contribution of all CAs present in the biological sample with an additional effect due to diffusion/transport of $C_{i}$ through the membranes (Sültemeyer and Rinast, 1996; Tolleter et al., 2017). When a periplasmic CA is present, as it is the case in C. reinhardtii cells with an active CCM, its activity dominates the exchange kinetics (Sültemeyer and Rinast, 1996). MIMS is so far the most reliable method for CA activity measurements in biological samples and is particularly suitable for in vivo measurements on algae (Dang et al., 2014; Benlloch et al., 2015; Tolleter et al., 2017), cyanobacteria (Whitehead et al., 2014), corals (Tansik et al., 2015), and plants (Peltier et al., 1995; Clausen et al., 2005; Burén et al., 2011; Benlloch et al., 2015). In vitro, the use MIMS and $\mathrm{H}^{13} \mathrm{CO}_{3}{ }^{-}$ has also allowed unraveling the existence of a light-induced $\mathrm{CO}_{2}$ production by the PSII (Koroidov et al., 2014; Shevela et al., 2020).

\section{FUTURE DEVELOPMENTS AND PERSPECTIVES}

Although MIMS is more than 50 years old, its usage has only recently become popular (Ketola and Lauritsen, 2016). The recent development in setups and analytical protocols and its popularity helped pushed the limits of our knowledge in the biology of photosynthetic microorganisms at various scales (Burlacot et al., 2020a).

Gas exchange measurements, chlorophyll fluorescence (Maxwell and Johnson, 2000), and electrochromism measurements (Bailleul et al., 2010) are the three main tools available to measure photosynthetic activity in microalgae and cyanobacteria on intact organisms. Simultaneous measurements of gas exchange by MIMS and chlorophyll fluorescence have allowed for correlating energy dissipation processes with $\mathrm{CO}_{2}$ and $\mathrm{O}_{2}$ photoreduction occurring during photosynthesis (Sültemeyer et al., 1989; Burlacot and Peltier, 2018; Ware et al., 2020). However, our understanding is still limited by the functional redundancy of many mechanisms and their interaction with cryptic mechanisms such as cyclic electron flow, which are not easily experimentally accessible. Further coupling of these methods, allowing for instance parallel measurement of gas exchange by MIMS and cyclic electron flow by electrochromism, together with an increased accessibility to genetic resources, should provide in the future new insights on how the main photosynthetic processes are regulated and interact during acclimation to various environmental situations.

In the perspective of large-scale biofuel production by microalgae or cyanobacteria, recent research has focused on the design and use of photobioreactors coupled to MIMS for the analysis of volatile compounds of interest. These setups have been used to measure real time productions of $\mathrm{H}_{2}$ (Tamburic et al., 2011; Zhang et al., 2015) or ethylene (Zavrel et al., 2016) during medium and long-term cultivation of microalgae or cyanobacteria. In the future, MIMS could be used to study and optimize the production in photobioreactors of volatile hydrocarbons by engineered photosynthetic cells.

Further miniaturization and decreasing prices of mass spectrometers should enable an even larger number of laboratories to have access to MIMS in the future, thus accelerating our understanding of how photosynthetic microorganisms impact the atmosphere of our planet (Burlacot et al., 2020a). The use or application of MIMS in the field opens a new era of evaluating the occurrence and ecological relevance of molecular mechanisms in natural environment.

\section{DATA AVAILABILITY STATEMENT}

All datasets presented in this study are included in the article/ Supplementary Material.

\section{AUTHOR CONTRIBUTIONS}

$\mathrm{AB}$ and $\mathrm{GP}$ designed the illustrating experiments. $\mathrm{AB}$ performed the experiments. $\mathrm{AB}$ and $\mathrm{FB}$ designed the software. $\mathrm{FB}$ developed the software with supervision from $A B$. $A B, Y L-B$ and GP wrote the manuscript.

\section{FUNDING}

This work was supported by the French Agence Nationale de la Recherche (ANR) projects OTOLHYD and PHOTOALKANE. AB is a recipient of a CEA international $\mathrm{PhD}$ studentship (Irtelis).

\section{ACKNOWLEDGMENTS}

The authors thank Dr. Solène Moulin for drawings used in Figures 4, 5, 7, and 8 and Dr. Bernard Genty for stimulating discussions. The authors acknowledge the European Union Regional Developing Fund, the Region Provence-Alpes-Côte d'Azur, the French Ministry of Research, and the CEA for funding the HelioBiotec platform.

\section{SUPPLEMENTARY MATERIAL}

The Supplementary Material for this article can be found online at: https://www.frontiersin.org/articles/10.3389/fpls.2020.01302/ full\#supplementary-material 


\section{REFERENCES}

Abou Hamdan, A., Dementin, S., Liebgott, P.-P., Gutierrez-Sanz, O., Richaud, P., De Lacey, A. L., et al. (2012). Understanding and Tuning the Catalytic Bias of Hydrogenase. J. Am. Chem. Soc 134, 8368-8371. doi: 10.1021/ja301802r

Allahverdiyeva, Y., Mustila, H., Ermakova, M., Bersanini, L., Richaud, P., Ajlani, G., et al. (2013). Flavodiiron proteins Flv1 and Flv3 enable cyanobacterial growth and photosynthesis under fluctuating light. Proc. Natl. Acad. Sci. U. S. A. 110, 41114116. doi: $10.1073 /$ pnas. 1221194110

Badger, M. R., and Andrews, T. J. (1982). Photosynthesis and inorganic carbon usage by the marine cyanobacterium, Synechococcus sp. Plant Physiol. 70, 517523. doi: 10.1104/pp.70.2.517

Badger, M. R., Kaplan, A., and Berry, J. A. (1980). Internal inorganic carbon pool of Chlamydomonas reinhardtii. Plant Physiol. 66, 407-413. doi: 10.1104/ pp.66.3.407

Badger, M. R., Palmqvist, K., and Yu, J.-W. (1994). Measurement of $\mathrm{CO}_{2}$ and $\mathrm{HCO}_{3}{ }^{-}$ fluxes in cyanobacteria and microalgae during steady-state photosynthesis. Physiol. Plant. 90, 529-536. doi: 10.1111/j.1399-3054.1994.tb08811.x

Badger, M. R., von Caemmerer, S., Ruuska, S., and Nakano, H. (2000). Electron flow to oxygen in higher plants and algae: rates and control of direct photoreduction (Mehler reaction) and rubisco oxygenase. Phil. Trans. R. Soc B. 355, 1433-1446. doi: $10.1098 /$ rstb.2000.0704

Badger, M. R. (1985). Photosynthetic oxygen exchange. Ann. Rev. Plant Physiol. 36, 27-53. doi: 10.1146/annurev.pp.36.060185.000331

Bailleul, B., Cardol, P., Breyton, C., and Finazzi, G. (2010). Electrochromism: a useful probe to study algal photosynthesis. Photosynth. Res. 106, 179. doi: $10.1007 /$ s11120-010-9579-z

Bailleul, B., Berne, N., Murik, O., Petroutsos, D., Prihoda, J., Tanaka, A., et al. (2015). Energetic coupling between plastids and mitochondria drives $\mathrm{CO}_{2}$ assimilation in diatoms. Nature 524, 366. doi: 10.1038/nature14599

Bailleul, B., Park, J., Brown, C. M., Bidle, K. D., Lee, S. H., and Falkowski, P. G. (2017). Direct measurements of the light dependence of gross photosynthesis and oxygen consumption in the ocean. Limnol. Oceanogr. 62, 1066-1079. doi: 10.1002/lno.10486

Beckmann, K., Messinger, J., Badger, M. R., Wydrzynski, T., and Hillier, W. (2009). On-line mass spectrometry: membrane inlet sampling. Photosynth. Res. 102, 511-522. doi: 10.1007/s11120-009-9474-7

Benlloch, R., Shevela, D., Hainzl, T., Grundström, C., Shutova, T., Messinger, J., et al. (2015). Crystal structure and functional characterization of photosystem II-associated carbonic anhydrase CAH3 in Chlamydomonas reinhardtii. Plant Physiol. 167, 950-962. doi: 10.1104/pp.114.253591

Ben-Zvi, O., Dafni, E., Feldman, Y., and Yacoby, I. (2019). Re-routing photosynthetic energy for continuous hydrogen production in vivo. Biotechnol. Biofuel 12, 266. doi: 10.1186/s13068-019-1608-3

Berlier, Y. M., Dimon, B., Fauque, G., and Lespinat, P. A. (1985). "Direct massspectrometric monitoring of the metabolism and isotope exchange in enzymic and microbiological investigations," in Gas Enzymology. Eds. H. Degn, R. P. Cox and H. Toftlund (Springer Netherlands: Dordrecht), pp 17-35.

Bethke, P. C., Badger, M. R., and Jones, R. L. (2004). Apoplastic synthesis of nitric oxide by plant tissues. Plant Cell 16, 332-341. doi: 10.1105/tpc.017822

Boatman, T. G., Davey, P. A., Lawson, T., and Geider, R. J. (2018). $\mathrm{CO}_{2}$ modulation of the rates of photosynthesis and light-dependent $\mathrm{O}_{2}$ consumption in Trichodesmium. J. Exp. Bot. 70, 589-597. doi: 10.1093/jxb/ery368

Burén, S., Ortega-Villasante, C., Blanco-Rivero, A., Martínez-Bernardini, A., Shutova, T., Shevela, D., et al. (2011). Importance of post-translational modifications for functionality of a chloroplast-localized carbonic anhydrase (CAH1) in Arabidopsis thaliana. PLoS One 6, e21021. doi: 10.1371/journal.pone.0021021

Burlacot, A., and Peltier, G. (2018). "Photosynthetic electron transfer pathways during hydrogen photoproduction in green algae: mechanisms and limitations," in Microalgal Hydrogen Production: Achievements and Perspectives. Eds. M. Seibert and G. Torzillo (London, U. K.: The Royal Society of Chemistry), pp 189-212. doi: 10.1039/9781849737128-00189

Burlacot, A., Sawyer, A., Cuiné, S., Auroy-Tarrago, P., Blangy, S., Happe, T., et al. (2018). Flavodiiron-mediated $\mathrm{O}_{2}$ photoreduction links $\mathrm{H}_{2}$ production with $\mathrm{CO}_{2}$ fixation during the anaerobic induction of photosynthesis. Plant Physiol. $177,1639-1649$.

Burlacot, A., Li-Beisson, Y., and Peltier, G. (2020a). Membrane inlet mass spectrometry at the crossroads of photosynthesis, biofuel and climate research. Plant Physiol. 183, 451-45. doi: 10.1104/pp.20.00368
Burlacot, A., Richaud, P., Gosset, A., Li-Beisson, Y., and Peltier, G. (2020b). Algal photosynthesis converts nitric oxide into nitrous oxide. Proc. Nat. Acad. Sci. U. S. A. 117 (5), 2704-2709. doi: 10.1073/pnas.1915276117

Cano, M., Volbeda, A., Guedeney, G., Aubert-Jousset, E., Richaud, P., Peltier, G., et al. (2014). Improved oxygen tolerance of the Synechocystis sp. PCC 6803 bidirectional hydrogenase by site-directed mutagenesis of putative residues of the gas diffusion channel. Int. J. Hyd. Energ. 39, 16872-16884. doi: 10.1016/ j.ijhydene.2014.08.030

Catalanotti, C., Yang, W., Posewitz, M., and Grossman, A. (2013). Fermentation metabolism and its evolution in algae. Front. Plant Sci. 4, 150. doi: 10.3389/ fpls.2013.00150

Chatton, E., Labasque, T., de La Bernardie, J., Guihéneuf, N., Bour, O., and Aquilina, L. (2017). Field continuous measurement of dissolved gases with a CF-MIMS: applications to the physics and biogeochemistry of groundwater flow. Environ. Sci. Technol. 51, 846-854. doi: 10.1021/acs.est.6b03706

Chaux, F., Burlacot, A., Mekhalfi, M., Auroy, P., Blangy, S., Richaud, P., et al. (2017). Flavodiiron proteins promote fast and transient $\mathrm{O}_{2}$ photoreduction in Chlamydomonas. Plant Physiol. 174, 1825-1836. doi: 10.1104/pp.17.00421

Cheah, M. H., Millar, A. H., Myers, R. C., Day, D. A., Roth, J., Hillier, W., et al. (2014). Online oxygen kinetic isotope effects using membrane inlet mass spectrometry can differentiate between oxidases for mechanistic studies and calculation of their contributions to oxygen consumption in whole tissues. Anal. Chem. 86, 5171-5178. doi: 10.1021/ac501086n

Chua, E. J., Savidge, W., Short, R. T., Cardenas-Valencia, A. M., and Fulweiler, R. W. (2016). A review of the emerging field of underwater mass spectrometry. Front. Mar. Sci. 3, 209. doi: 10.3389/fmars.2016.00209

Clausen, J., Beckmann, K., Junge, W., and Messinger, J. (2005). Evidence that bicarbonate is not the substrate in photosynthetic oxygen evolution. Plant Physiol. 139, 1444-1450. doi: 10.1104/pp.105.068437

Conrath, U., Amoroso, G., Köhle, H., and Sültemeyer, D. F. (2004). Non-invasive online detection of nitric oxide from plants and some other organisms by mass spectrometry. Plant J. 38, 1015-1022. doi: 10.1111/j.1365-313X.2004.02096.x

Cournac, L., Dimon, B., and Peltier, G. (1993). Evidence for ${ }^{18} \mathrm{O}$ labeling of photorespiratory $\mathrm{CO}_{2}$ in photoautotrophic cell cultures of higher plants illuminated in the presence of ${ }^{18} \mathrm{O}_{2}$. Planta 190, 407-414. doi: 10.1007/ BF00196970

Cournac, L., Mus, F., Bernard, L., Guedeney, G., Vignais, P., and Peltier, G. (2002). Limiting steps of hydrogen production in Chlamydomonas reinhardtii and Synechocystis PCC 6803 as analysed by light-induced gas exchange transients. Int. J. Hydrog. Energy 27, 1229-1237. doi: 10.1016/S0360-3199(02)00105-2

Cournac, L., Guedeney, G., Peltier, G., and Vignais, P. M. (2004). Sustained photoevolution of molecular hydrogen in a mutant of Synechocystis sp strain PCC 6803 deficient in the type I NADPH-dehydrogenase complex. J. Bacteriol. 186, 1737-1746. doi: 10.1128/JB.186.6.1737-1746.2003

Csonka, C., Páli, T., Bencsik, P., Görbe, A., Ferdinandy, P., and Csont, T. (2015). Measurement of NO in biological samples. Brit. J. Pharmacol. 172, 1620-1632. doi: $10.1111 /$ bph.12832

Curien, G., Flori, S., Villanova, V., Magneschi, L., Giustini, C., Forti, G., et al. (2016). The Water to Water Cycles in Microalgae. Plant Cell Physiol. 57, 13541363. doi: $10.1093 / \mathrm{pcp} / \mathrm{pcw} 048$

Dang, K. V., Plet, J., Tolleter, D., Jokel, M., Cuine, S., Carrier, P., et al. (2014). Combined increases in mitochondrial cooperation and oxygen photoreduction compensate for deficiency in cyclic electron flow in Chlamydomonas reinhardtii. Plant Cell 26, 3036-3050. doi: 10.1105/tpc.114.126375

De Mia, M., Lemaire, S. D., Choquet, Y., and Wollman, F.-A. (2019). Nitric oxide remodels the photosynthetic apparatus upon S-starvation in Chlamydomonas reinhardtii. Plant Physiol. 179, 718-731. doi: 10.1104/pp.18.01164

Degn, H. (1992). Membrane inlet mass spectrometry in pure and applied microbiology. J. Microbiol. Methods 15, 185-197. doi: 10.1016/0167-7012(92) 90039-7

Douchi, D., Liang, F., Cano, M., Xiong, W., Wang, B., Maness, P.-C., et al. (2019). Membrane-Inlet Mass Spectrometry enables a quantitative understanding of inorganic carbon uptake flux and carbon concentrating mechanisms in metabolically engineered cyanobacteria. Front. Microbiol. 10, 1356-1356. doi: 10.3389/fmicb.2019.01356

Eilenberg, H., Weiner, I., Ben-Zvi, O., Pundak, C., Marmari, A., Liran, O., et al. (2016). The dual effect of a ferredoxin-hydrogenase fusion protein in vivo: successful divergence of the photosynthetic electron flux towards hydrogen 
production and elevated oxygen tolerance. Biotechnol. Biofuels 9, 182. doi: 10.1186/s13068-016-0601-3

Einbinder, S., Gruber, D. F., Salomon, E., Liran, O., Keren, N., and Tchernov, D. (2016). Novel adaptive photosynthetic characteristics of mesophotic symbiotic microalgae within the reef-building coral, Stylophora pistillata. Front. Marine Sci. 3, 195. doi: 10.3389/fmars.2016.00195

Erbes, D. L., King, D., and Gibbs, M. (1979). Inactivation of hydrogenase in cellfree extracts and whole cells of Chlamydomonas reinhardi by oxygen. Plant Physiol. 63, 1138-1142. doi: 10.1104/pp.63.6.1138

Ermakova, M., Huokko, T., Richaud, P., Bersanini, L., Howe, C. J., Lea-Smith, D. J., et al. (2016). Distinguishing the roles of thylakoid respiratory terminal oxidases in the cyanobacterium Synechocystis sp. PCC 6803. Plant Physiol. 171, 13071319. doi: $10.1104 /$ pp. 16.00479

Falkowski, P., and Kolber, Z. (1995). Variations in chlorophyll fluorescence yields in phytoplankton in the world oceans. Func. Plant Biol. 22, 341-355. doi: 10.1071/PP9950341

Ferrón, S., del Valle, D. A., Björkman, K. M., Quay, P. D., Church, M. J., and Karl, D. M. (2016). Application of membrane inlet mass spectrometry to measure aquatic gross primary production by the $18 \mathrm{O}$ in vitro method. Limnol. Oceanogr. Methods 14, 610-622. doi: 10.1002/lom3.10116

Field, C. B., Behrenfeld, M. J., Randerson, J. T., and Falkowski, P. (1998). Primary production of the biosphere: integrating terrestrial and oceanic components. Science 281, 237-240. doi: 10.1126/science.281.5374.237

Filina, V., Grinko, A., and Ermilova, E. (2019). Truncated hemoglobins 1 and 2 are implicated in the modulation of phosphorus deficiency-induced nitric oxide levels in Chlamydomonas. Cells 8, 947. doi: 10.3390/cells8090947

Fisher, N. L., and Halsey, K. H. (2016). Mechanisms that increase the growth efficiency of diatoms in low light. Photosynth. Res. 129, 183-197. doi: 10.1007/ s11120-016-0282-6

Florin, L., Tsokoglou, A., and Happe, T. (2001). A novel type of iron hydrogenase in the green alga Scenedesmus obliquus is linked to the photosynthetic electron transport chain. J. Biol. Chem. 276, 6125-6132. doi: 10.1074/jbc.M008470200

Fratamico, A., Tocquin, P., and Franck, F. (2016). The chlorophyll a fluorescence induction curve in the green microalga Haematococcus pluvialis: further insight into the nature of the P-S-M fluctuation and its relationship with the "low-wave" phenomenon at steady-state. Phot. Res. 128, 271-285. doi: 10.1007/s11120-016-0241-2

Gauquelin, C., Baffert, C., Richaud, P., Kamionka, E., Etienne, E., Guieysse, D., et al. (2018). Roles of the F-domain in [FeFe] hydrogenase. Biochim. Biophys. Acta Bioenerg. 1859, 69-77. doi: 10.1016/j.bbabio.2017.08.010

Genty, B., Briantais, J. M., and Baker, N. R. (1989). The relationship between the quantum yield of photosynthetic electron transport and quenching of chlorophyll fluorescence. Biochim. Biophys. Acta 990, 87-92. doi: 10.1016/ S0304-4165(89)80016-9

Gerster, R., Dimon, B., and Peybernes, A. (1974). "The fate of oxygen in photosynthesis," in Proceeding of the third international congress on photosynthesis. (Amsterdam: Elsevier Publishing Co. Ltd.), pp 1589-1600.

Gerster, R. H., Dimon, B., Tournier, P., and Peybernes, A. (1977). "Metabolism of oxygen during photorespiration," in Stable isotopes in the life of sciences. (Vienna Austria: IAEA), pp 293-301.

Gerster, R. (1971). An attempt to interpret the kinetics of isotope exchange between $\mathrm{C}^{18} \mathrm{O}_{2}$ and the water of a leaf: Experiments in the dark. Planta 97 , 155-172. doi: 10.1007/BF00386763

Ghysels, B., Godaux, D., Matagne, R. F., Cardol, P., and Franck, F. (2013). Function of the chloroplast hydrogenase in the microalga Chlamydomonas: The role of hydrogenase and state transitions during photosynthetic activation in anaerobiosis. PLoS One 8, e64161. doi: 10.1371/journal.pone.0064161

Giordano, M., Beardall, J., and Raven, J. A. (2005). $\mathrm{CO}_{2}$ concentration mechanisms in algae: mechanisms, environmental modulation, and evolution. Annu. Rev. Plant Biol. 56, 99-131. doi: 10.1146/annurev.arplant.56.032604.144052

Godaux, D., Bailleul, B., Berne, N., and Cardol, P. (2015). Induction of photosynthetic carbon fixation in anoxia relies on hydrogenase activity and Proton-Gradient Regulation-Like1-mediated cyclic electron flow in Chlamydomonas reinhardtii. Plant Physiol. 168, 648-658. doi: 10.1104/ pp.15.00105

Goreau, T. J., Kaplan, W. A., Wofsy, S. C., McElroy, M. B., Valois, F. W., and Watson, S. W. (1980). Production of $\mathrm{NO}_{2}{ }^{-}$and $\mathrm{N}_{2} \mathrm{O}$ by nitrifying bacteria at reduced concentrations of oxygen. Appl. Environ. Microbiol. 40, 526-532. doi: 10.1128/AEM.40.3.526-532.1980

Guieysse, B., Plouviez, M., Coilhac, M., and Cazali, L. (2013). Nitrous Oxide $\left(\mathrm{N}_{2} \mathrm{O}\right)$ production in axenic Chlorella vulgaris microalgae cultures: evidence, putative pathways, and potential environmental impacts. Biogeosciences 10, 6737-6746. doi: 10.5194/bg-10-6737-2013

Hanson, D. T., Franklin, L. A., Samuelsson, G., and Badger, M. R. (2003). The Chlamydomonas reinhardtii cia3 mutant lacking a thylakoid lumen-localized carbonic anhydrase is limited by $\mathrm{CO}_{2}$ supply to rubisco and not photosystem II function in vivo. Plant Physiol. 132, 2267-2275. doi: 10.1104/pp.103.023481

Helman, Y., Tchernov, D., Reinhold, L., Shibata, M., Ogawa, T., Schwarz, R., et al. (2003). Genes encoding a-type flavoproteins are essential for photoreduction of $\mathrm{O}_{2}$ in cyanobacteria. Curr. Biol. 13, 230-235. doi: 10.1016/S0960-9822(03) 00046-0

Hemschemeier, A., Düner, M., Casero, D., Merchant, S. S., Winkler, M., and Happe, T. (2013). Hypoxic survival requires a 2-on-2 hemoglobin in a process involving nitric oxide. Proc. Nat. Acad. Sci. U. S. A. 110, 10854-10859. doi: 10.1073/pnas. 1302592110

Hoberman, H. D., and Rittenberg, D. (1943). Biological catalysis of the exchange reaction between water and hydrogen. J. Biol. Chem. 147, 211-227.

Hoch, G., and Kok, B. (1963). A mass spectrometer inlet system for sampling gases dissolved in liquid phases. Arch. Biochem. Biophys. 101, 160-170. doi: 10.1016/ 0003-9861(63)90546-0

Hohmann-Marriott, M. F., and Blankenship, R. E. (2011). Evolution of photosynthesis. Annu. Rev. Plant Biol. 62, 515-548. doi: 10.1146/annurevarplant-042110-103811

Hunt, P. P., and Smith, H. A. (1961). The separation of hydrogen, deuterium and hydrogen deuteride mixtures by gas chromatography. J. Phys. Chem. 65, 87-89. doi: 10.1021/j100819a027

IPCC (2013). Climate Change 2013: The Physical Science Basis. Contribution of Working Group I to the Fifth Assessment Report of the Intergovernmental Panel on Climate Change (Cambridge, United Kingdom and New York, NY, USA: Cambridge University Press).

Jans, F., Mignolet, E., Houyoux, P. A., Cardol, P., Ghysels, B., Cuine, S., et al. (2008). A type II NAD(P) H dehydrogenase mediates light-independent plastoquinone reduction in the chloroplast of Chlamydomonas. Proc. Natl. Acad. Sci. U. S. A. 105, 20546-20551. doi: 10.1073/pnas.0806896105

Jensen, B. B., and Cox, R. P. (1988). "Measurement of hydrogen exchange and nitrogen uptake by mass spectrometry," in Methods in Enzymology, vol. 167. (San Diego, USA: Academic Press), pp 467-474.

Johnson, R. C., Cooks, R. G., Allen, T. M., Cisper, M. E., and Hemberger, P. H. (2000). Membrane introduction mass spectrometry: trends and applications. Mass Spectom. Rev. 19, 1-37. doi: 10.1002/(SICI)1098-2787(2000)19:1<1::AIDMAS1>3.0.CO;2-Y

Jokel, M., Nagy, V., Tóth, S. Z., Kosourov, S., and Allahverdiyeva, Y. (2019). Elimination of the flavodiiron electron sink facilitates long-term $\mathrm{H}_{2}$ photoproduction in green algae. Biotechnol. Biofuels 12, 280. doi: 10.1186/ s13068-019-1618-1

Jouanneau, Y., Kelley, B. C., Berlier, Y., Lespinat, P. A., and Vignais, P. M. (1980). Continuous monitoring, by mass spectrometry, of $\mathrm{H}_{2}$ production and recycling in Rhodopseudomonas capsulata. J. Bacteriol. 143, 628-636. doi: 10.1128/ JB.143.2.628-636.1980

Ketola, R. A., and Lauritsen, F. R. (2016). "Membrane inlet mass spectrometry (MIMS) in historical perspective," in The Encyclopedia of Mass Spectrometry. Eds. M. L. Gross and R. M. Caprioli (Boston: Elsevier), pp 143-148.

Konermann, L., Messinger, J., and Hillier, W. (2008). "Mass spectrometry-based methods for studying kinetics and dynamics in biological systems," in Biophysical Techniques in Photosynthesis. Eds. T. J. Aartsma and J. Matysik (Springer Netherlands: Dordrecht), pp 167-190.

Kong, F., Burlacot, A., Liang, Y., Légeret, B., Alseekh, S., Brotman, Y., et al. (2018). Interorganelle communication: peroxisomal MALATE DEHYDROGENASE2 connects lipid catabolism to photosynthesis through redox coupling in Chlamydomonas. Plant Cell 30, 1824-1847. doi: 10.1105/tpc.18.00361

Koroidov, S., Shevela, D., Shutova, T., Samuelsson, G., and Messinger, J. (2014). Mobile hydrogen carbonate acts as proton acceptor in photosynthetic water oxidation. Proc. Acad. Nat. Sci. U. S. A. 111, 6299-6304. doi: 10.1073/ pnas. 1323277111 
Koroidov, S., Anderlund, M. F., Styring, S., Thapper, A., and Messinger, J. (2015). First turnover analysis of water-oxidation catalyzed by Co-oxide nanoparticles. Energ. Environ. Sci. 8, 2492-2503. doi: 10.1039/C5EE00700C

Kosourov, S., Jokel, M., Aro, E.-M., and Allahverdiyeva, Y. (2018). A new approach for sustained and efficient $\mathrm{H}_{2}$ photoproduction by Chlamydomonas reinhardtii. Energy Environ. Sci. 11, 1431-1436. doi: 10.1039/C8EE00054A

Kotiaho, T., and Lauritsen, F. R. (2002). "Membrane inlet mass spectrometry," in Comprehensive Analytical Chemistry, vol. 37. (Netherlands: Elsevier), pp 531557.

Leroux, F., Dementin, S., Burlat, B., Cournac, L., Volbeda, A., Champ, S., et al. (2008). Experimental approaches to kinetics of gas diffusion in hydrogenase. Proc. Nat. Acad. Sci. U. S. A. 105, 11188-11193. doi: 10.1073/pnas.0803689105

$\mathrm{Li}, \mathrm{H}$., and Wan, A. (2015). Fluorescent probes for real-time measurement of nitric oxide in living cells. Analyst 140, 7129-7141. doi: 10.1039/C5AN01628B

Liebgott, P.-P., de Lacey, A. L., Burlat, B., Cournac, L., Richaud, P., Brugna, M., et al. (2011). Original design of an oxygen-tolerant [NiFe] hydrogenase: major effect of a valine-to-cysteine mutation near the active site. J. Am. Chem. Soc. 133, 986-997. doi: 10.1021/ja108787s

Liran, O., Semyatich, R., Milrad, Y., Eilenberg, H., Weiner, I., and Yacoby, I. (2016). Microoxic niches within the thylakoid stroma of air-grown Chlamydomonas reinhardtii protect [FeFe]-hydrogenase and support hydrogen production under fully aerobic environment. Plant Physiol. 172, 264-271. doi: 10.1104/pp.16.01063

Lloyd, D., Scott, R. I., and Williams, T. N. (1983). Membrane inlet mass spectrometry - measurement of dissolved gases in fermentation liquids. Trends Biotechnol. 1, 60-63. doi: 10.1016/0167-7799(83)90071-9

Luimstra, V. M., Schuurmans, J. M., de Carvalho, C. F. M., Matthijs, H. C. P., Hellingwerf, K. J., and Huisman, J. (2019). Exploring the low photosynthetic efficiency of cyanobacteria in blue light using a mutant lacking phycobilisomes. Photosynth. Res. 141, 291-301. doi: 10.1007/s11120-019-00630-z

Lundsgaard, J. S., Grønlund, J., and Degn, H. (1978). Error in oxygen measurements in open systems owing to oxygen consumption in unstirred layer. Biotechnol. Bioeng. 20, 809-819. doi: 10.1002/bit.260200604

Mackinder, L. C. M., Chen, C., Leib, R. D., Patena, W., Blum, S. R., Rodman, M., et al. (2017). A spatial interactome reveals the protein organization of the algal $\mathrm{CO}_{2}$-concentrating mechanism. Cell 171, 133-147.e114. doi: 10.1016/ j.cell.2017.08.044

Mackinder, L. C. M. (2018). The Chlamydomonas $\mathrm{CO}_{2}$-concentrating mechanism and its potential for engineering photosynthesis in plants. New Phytol. 217, 54-61. doi: 10.1111/nph.14749

Maeda, K., Spor, A., Edel-Hermann, V., Heraud, C., Breuil, M.-C., Bizouard, F., et al. (2015). $\mathrm{N}_{2} \mathrm{O}$ production, a widespread trait in fungi. Sci. Rep. 5, 9697. doi: $10.1038 /$ srep09697

Manz, D.-H., Duan, P.-C., Dechert, S., Demeshko, S., Oswald, R., John, M., et al. (2017). Pairwise $\mathrm{H}_{2} / \mathrm{D}_{2}$ exchange and $\mathrm{H}_{2}$ substitution at a bimetallic dinickel (II) complex featuring two terminal hydrides. J. Am. Chem. Soc 139, 1672016731. doi: $10.1021 /$ jacs.7b08629

Maxwell, K., and Johnson, G. N. (2000). Chlorophyll fluorescence-a practical guide. J. Exp. Bot. 51, 659-668. doi: 10.1093/jexbot/51.345.659

Melis, A., Zhang, L. P., Forestier, M., Ghirardi, M. L., and Seibert, M. (2000). Sustained photobiological hydrogen gas production upon reversible inactivation of oxygen evolution in the green alga Chlamydomonas reinhardtii. Plant Physiol. 122, 127-135. doi: 10.1104/pp.122.1.127

Nagy, V., Podmaniczki, A., Vidal-Meireles, A., Tengölics, R., Kovács, L., Rákhely, G., et al. (2018). Water-splitting-based, sustainable and efficient $\mathrm{H}_{2}$ production in green algae as achieved by substrate limitation of the Calvin-BensonBassham cycle. Biotechnol. Biofuels 11, 69. doi: 10.1186/s13068-018-1069-0

Northrop, D. B., and Simpson, F. B. (1998). Kinetics of enzymes with isomechanisms: britton induced transport catalyzed by bovine carbonic anhydrase II, measured by rapid-flow mass spectrometry. Arch. Biochem. Biophys. 352, 288-292. doi: 10.1006/abbi.1997.0589

Palmqvist, K., Yu, J.-W., and Badger, M. R. (1994). Carbonic anhydrase activity and inorganic carbon fluxes in low- and high- $\mathrm{C}_{\mathrm{i}}$ cells of Chlamydomonas reinhardtii and Scenedesmus obliquus. Physiol. Plantarum 90, 537-547. doi: 10.1111/j.1399-3054.1994.tb08812.x

Peltier, G., and Thibault, P. (1985a). Light-dependent oxygen uptake, glycolate, and ammonia release in L-Methionine Sulfoximine-treated Chlamydomonas. Plant Physiol. 77, 281-284. doi: 10.1104/pp.77.2.281
Peltier, G., and Thibault, P. (1985b). Oxygen uptake in the light in Chlamydomonas. Evidence for persistent mitochondrial respiration. Plant Physiol. 79, 225-230. doi: 10.1104/pp.79.1.225

Peltier, G., Cournac, L., Despax, V., Dimon, B., Fina, L., Genty, B., et al. (1995). Carbonic anhydrase activity in leaves as measured in vivo by ${ }^{18} \mathrm{O}$ exchange between carbon dioxide and water. Planta 196, 732-739. doi: 10.1007/ BF01106768

Poulsen, A. K., Rompel, A., and McKenzie, C. J. (2005). Water oxidation catalyzed by a dinuclear Mn complex: a functional model for the oxygen-evolving center of photosystem II. Angewandte Chemie 44, 6916-6920. doi: 10.1002/anie.200502114

Price, G. D., Badger, M. R., Woodger, F. J., and Long, B. M. (2007). Advances in understanding the cyanobacterial $\mathrm{CO}_{2}$-concentrating-mechanism (CCM): functional components, $\mathrm{Ci}$ transporters, diversity, genetic regulation and prospects for engineering into plants. J. Exp. Bot. 59, 1441-1461. doi: 10.1093/jxb/erm112

Radmer, R. J., and Kok, B. (1976). Photoreduction of $\mathrm{O}_{2}$ pimes and replaces $\mathrm{CO}_{2}$ assimilation. Plant Physiol. 58, 336-340. doi: 10.1104/pp.58.3.336

Radmer, R., and Ollinger, O. (1980a). Isotopic composition of photosynthetic $\mathrm{O}_{2}$ flash yields in the presence of $\mathrm{H}_{2}{ }^{18} \mathrm{O}$ and $\mathrm{HC}^{18} \mathrm{O}_{-3}$. FEBS Lett. 110, 57-61. doi: $10.1016 / 0014-5793(80) 80022-6$

Radmer, R., and Ollinger, O. (1980b). "Measurement of the oxygen cycle : the mass spectrometric analysis of gases dissolved in a liquid phase," in Methods in Enzymology, vol. 69 . Ed. A. San Pietro (San Diego, USA: Academic Press), pp 547-560.

Radmer, R., and Ollinger, O. (1986). Do the higher oxidation states of the photosynthetic $\mathrm{O}_{2}$-evolving system contain bound $\mathrm{H}_{2} \mathrm{O}$ ? FEBS Lett. 195, 285-289. doi: 10.1016/S0076-6879(80)69054-5

Redding, K., Cournac, L., Vassiliev, I. R., Golbeck, J. H., Peltier, G., and Rochaix, J. D. (1999). Photosystem I is indispensable for photoautotrophic growth, $\mathrm{CO}_{2}$ fixation, and $\mathrm{H}_{2}$ photoproduction in Chlamydomonas reinhardtii. J. Biol. Chem. 274, 10466-10473. doi: 10.1074/jbc.274.15.10466

Reinfelder, J. R. (2011). Carbon concentrating mechanisms in eukaryotic marine phytoplankton. Annu. Rev. Mar. Sci. 3, 291-315. doi: 10.1146/annurevmarine-120709-142720

Rittenberg, D., and Krasna, A. I. (1955). Interaction of hydrogenase with hydrogen. Discuss. Faraday Soc 20, 185-189. doi: 10.1039/DF9552000185

Shevela, D., and Messinger, J. (2013). Studying the oxidation of water to molecular oxygen in photosynthetic and artificial systems by time-resolved membraneinlet mass spectrometry. Front. Plant Sci. 4, 473. doi: 10.3389/fpls.2013.00473

Shevela, D., Beckmann, K., Clausen, J., Junge, W., and Messinger, J. (2011). Membrane-inlet mass spectrometry reveals a high driving force for oxygen production by photosystem II. Proc. Nat. Acad. Sci. U. S. A. 108, 3602-3607. doi: $10.1073 /$ pnas. 1014249108

Shevela, D., Schröder, W. P., and Messinger, J. (2018). "Liquid-phase measurements of photosynthetic oxygen evolution," in Photosynthesis: Methods and Protocols. Ed. S. Covshoff (New York, NY: Springer New York), pp. 197-211. doi: 10.1007/978-1-4939-7786-4_11

Shevela, D., Do, H.-N., Fantuzzi, A., Rutherford, A. W., and Messinger, J. (2020). Bicarbonate-mediated $\mathrm{CO}_{2}$ formation on both sides of photosystem II. BIochem. 59, 2442-2449. doi: 10.1021/acs.biochem.0c00208

Silverman, D. N. (1982). "Carbonic anhydrase: oxygen-18 exchange catalyzed by an enzyme with rate-contributing proton-transfer steps," in Methods in Enzymology, vol. 87 . Ed. D. L. Purich (San Diego, USA: Academic Press), pp 732-752.

So, A. K. C., Van Spall, H. G. C., Coleman, J. R., and Espie, G. S. (1998). Catalytic exchange of ${ }^{18} \mathrm{O}$ from ${ }^{13} \mathrm{C}^{18} \mathrm{O}$-labelled $\mathrm{CO}_{2}$ by wild-type cells and ecaA, ecaB, and ccaA mutants of the cyanobacteria Synechococcus PCC7942 and Synechocystis PCC6803. Can. J. Bot. 76, 1153-1160. doi: 10.1139/b98-063

Sorigué, D., Légeret, B., Cuiné, S., Blangy, S., Moulin, S., Billon, E., et al. (2017). An algal photoenzyme converts fatty acids to hydrocarbons. Science 357, 903-907. doi: $10.1126 /$ science.aan6349

Sültemeyer, D., and Rinast, K.-A. (1996). The $\mathrm{CO}_{2}$ permeability of the plasma membrane of Chlamydomonas reinhardtii: mass-spectrometric ${ }^{18} \mathrm{O}$-exchange measurements from ${ }^{13} \mathrm{C}^{18} \mathrm{O}_{2}$ in suspensions of carbonic anhydrase-loaded plasma-membrane vesicles. Planta 200, 358-368. doi: 10.1007/BF00200304

Sültemeyer, D. F., Klug, K., and Fock, H. P. (1987). Effect of dissolved inorganic carbon on oxygen evolution and uptake by Chlamydomonas reinhardtii suspensions adapted to ambient and $\mathrm{CO}_{2}$-enriched air. Photosynth. Res. 12, 25-33. doi: 10.1007/BF00019148 
Sültemeyer, D. F., Miller, A. G., Espie, G. S., Fock, H. P., and Canvin, D. T. (1989). Active $\mathrm{CO}_{2}$ transport by the green alga Chlamydomonas reinhardtii. Plant Physiol. 89, 1213-1219. doi: 10.1104/pp.89.4.1213

Sültemeyer, D. F., Fock, H. P., and Canvin, D. T. (1990). Mass spectrometric measurement of intracellular carbonic anhydrase activity in high and low $\mathrm{C}_{\mathrm{i}}$ cells of Chlamydomonas. Plant Physiol. 94, 1250-1257. doi: 10.1104/pp.94.3.1250

Sültemeyer, D. F., Fock, H. P., and Canvin, D. T. (1991). Active uptake of inorganic carbon by Chlamydomonas reinhardtii: evidence for simultaneous transport of $\mathrm{HCO}_{3}{ }^{-}$and $\mathrm{CO}_{2}$ and characterization of active $\mathrm{CO}_{2}$ transport. Can. J. Bot. 69, 995-1002. doi: 10.1139/b91-128

Sültemeyer, D., Biehler, K., and Fock, H. P. (1993). Evidence for the contribution of pseudocyclic photophosphorylation to the energy requirement of the mechanism for concentrating inorganic carbon in Chlamydomonas. Planta 189, 235-242. doi: 10.1007/BF00195082

Sültemeyer, D., Klughammer, B., Badger, M. R., and Dean Price, G. (1998). Fast induction of high-affinity $\mathrm{HCO}_{3}{ }^{-}$transport in cyanobacteria. Plant Physiol. 116, 183-192. doi: 10.1104/pp.116.1.183

Tamburic, B., Zemichael, F. W., Crudge, P., Maitland, G. C., and Hellgardt, K. (2011). Design of a novel flat-plate photobioreactor system for green algal hydrogen production. Int. J. Hydrogen Energy 36, 6578-6591. doi: 10.1016/j.ijhydene.2011.02.091

Tansik, A. L., Fitt, W. K., and Hopkinson, B. M. (2015). External carbonic anhydrase in three Caribbean corals: quantification of activity and role in $\mathrm{CO}_{2}$ uptake. Coral Reefs 34, 703-713. doi: 10.1007/s00338-015-1289-8

Tolleter, D., Ghysels, B., Alric, J., Petroutsos, D., Tolstygina, I., Krawietz, D., et al. (2011). Control of hydrogen photoproduction by the proton gradient generated by cyclic electron flow in Chlamydomonas reinhardtii. Plant Cell 23, 2619-2630. doi: 10.1105/tpc.111.086876

Tolleter, D., Chochois, V., Poiré, R., Price, G. D., and Badger, M. R. (2017). Measuring $\mathrm{CO}_{2}$ and $\mathrm{HCO}_{3}{ }^{-}$permeabilities of isolated chloroplasts using a MIMS- ${ }^{18} \mathrm{O}$ approach. J. Exp. Bot. 68, 3915-3924. doi: 10.1093/jxb/erx188

Tóth, S. Z., and Yacoby, I. (2019). Paradigm shift in algal $\mathrm{H}_{2}$ production: bypassing competitive processes. Trends Biotechnol. 37, 1159-1163. doi: 10.1016/ j.tibtech.2019.05.001

van der Oost, J., and Cox, R. P. (1988). Hydrogenase activity in nitrate-grown cells of the unicellular cyanobacterium Cyanothece PCC 7822. Arch. Microbiol. 151, 40-43. doi: 10.1007/BF00444666

Vignais, P. M., Henry, M.-F., Berlier, Y., and Lespinat, P. A. (1982). Effect of $\mathrm{pH}$ on $\mathrm{H}-{ }^{2} \mathrm{H}$ exchange, $\mathrm{H}_{2}$ production and $\mathrm{H}_{2}$ uptake, catalysed by the membranebound hydrogenase of Paracoccus denitrificans. Biochim. Biophys. Acta Bioenerg. 681, 519-529. doi: 10.1016/0005-2728(82)90195-5

Vignais, P. M., Cournac, L., Hatchikian, E. C., Elsen, S., Serebryakova, L., Zorin, N., et al. (2002). Continuous monitoring of the activation and activity of [NiFe]- hydrogenases by membrane-inlet mass spectrometry. Int. J. Hyd. Energ. 27, 1441-1448. doi: 10.1016/S0360-3199(02)00114-3

Vignais, P. M. (2005). H/D exchange reactions and mechanistic aspects of the hydrogenases. Coord. Chem. Rev. 249, 1677-1690. doi: 10.1016/j.ccr.2005.01.026

Wang, Y., and Spalding, M. H. (2014). Acclimation to very low $\mathrm{CO}_{2}$ : contribution of limiting $\mathrm{CO}_{2}$ inducible proteins, LCIB and LCIA, to inorganic carbon uptake in Chlamydomonas reinhardtii. Plant Physiol. 166, 2040-2050. doi: 10.1104/ pp.114.248294

Wang, R. T. (1980). “Amperometric hydrogen electrode," in Methods in Enzymology, vol. 69 . Ed. A. San Pietro (San Diego, USA: Academic Press), pp 409-413.

Ware, M. A., Hunstiger, D., Cantrell, M., and Peers, G. (2020). A chlorophyte alga utilizes alternative electron transport for primary photoprotection. Plant Physiol. 183, 1735-1748. doi: 10.1104/pp.20.00373

Whitehead, L., Long, B. M., Price, G. D., and Badger, M. R. (2014). Comparing the in vivo function of $\alpha$-carboxysomes and $\beta$-carboxysomes in two model cyanobacteria. Plant Physiol. 165, 398-411. doi: 10.1104/pp.114.237941

Xu, T., Yin, C.-J. M., Wodrich, M. D., Mazza, S., Schultz, K. M., Scopelliti, R., et al. (2016). A functional model of [Fe]-hydrogenase. J. Am. Chem. Soc 138, 3270-3273. doi: 10.1021/jacs.5b12095

Yu, J., Price, G., and Badger, M. (1994). Characterisation of $\mathrm{CO}_{2}$ and $\mathrm{HCO}_{3}{ }^{-}$uptake during steady-state photosynthesis in the cyanobacterium Synechococcus PCC7942. Funct. Plant Biol. 21, 185-195. doi: 10.1071/PP9940185

Zavřel, T., Knoop, H., Steuer, R., Jones, P. R., Červený, J., and Trtílek, M. (2016). A quantitative evaluation of ethylene production in the recombinant cyanobacterium Synechocystis sp. PCC 6803 harboring the ethylene-forming enzyme by membrane inlet mass spectrometry. Biores. Technol. 202, 142-151. doi: 10.1016/j.biortech. 2015.11.062

Zhang, D., Dechatiwongse, P., del Rio-Chanona, E. A., Maitland, G. C., Hellgardt, K., and Vassiliadis, V. S. (2015). Modelling of light and temperature influences on cyanobacterial growth and biohydrogen production. Algal Res. 9, 263-274. doi: 10.1016/j.algal.2015.03.015

Conflict of Interest: The authors declare that the research was conducted in the absence of any commercial or financial relationships that could be construed as a potential conflict of interest.

Copyright (c) 2020 Burlacot, Burlacot, Li-Beisson and Peltier. This is an open-access article distributed under the terms of the Creative Commons Attribution License (CC BY). The use, distribution or reproduction in other forums is permitted, provided the original author(s) and the copyright owner(s) are credited and that the original publication in this journal is cited, in accordance with accepted academic practice. No use, distribution or reproduction is permitted which does not comply with these terms. 